H.

1.

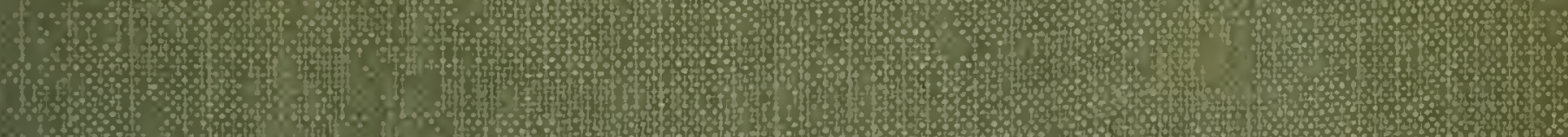

\%

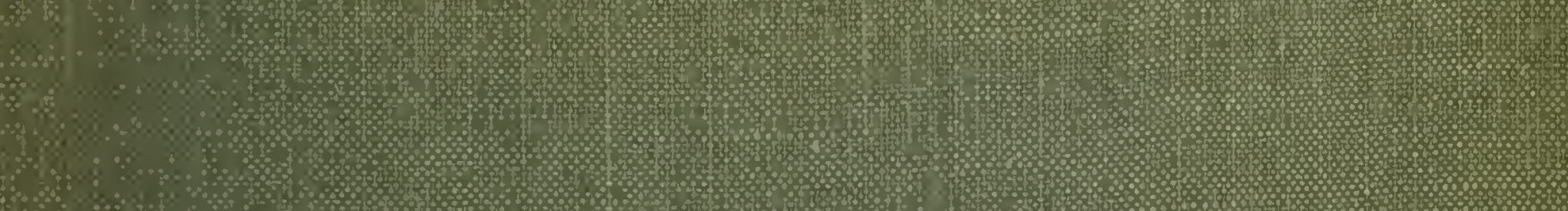

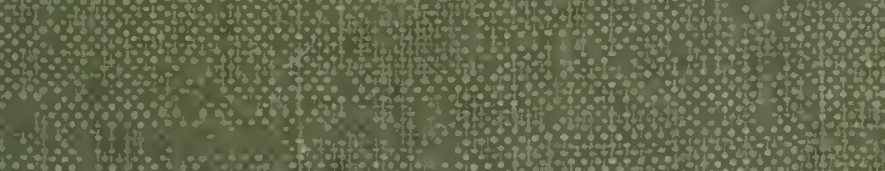

s.

ing

1.

13.

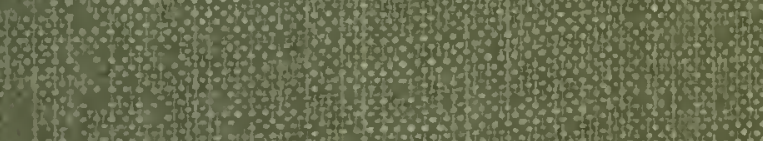

\%

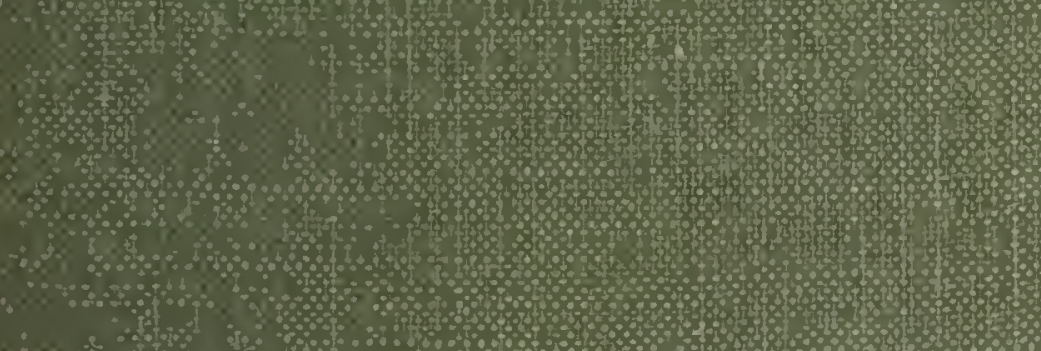

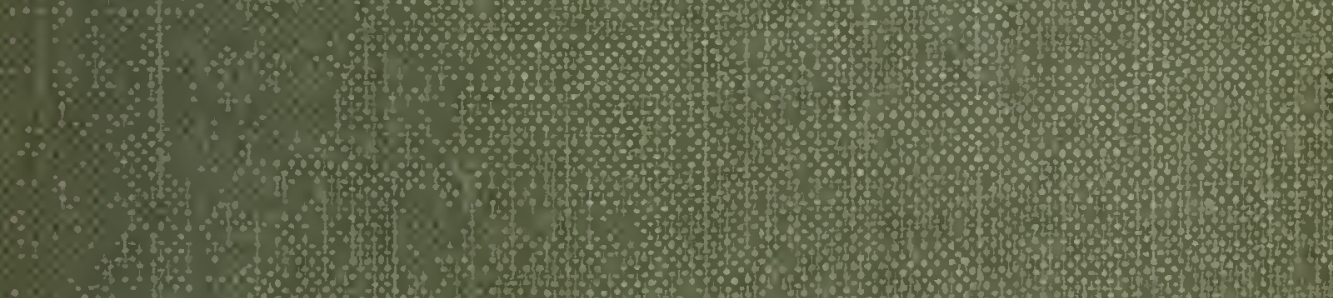

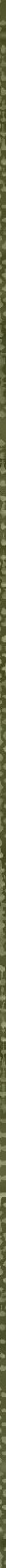

\% 
. $11226484^{\prime}$

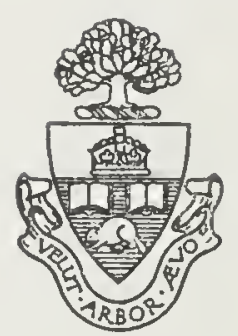

Library

of the

University of Toronto 


$$
w 6
$$






\section{AIR-BREATHERS OF THE COAL PRRIOD.}

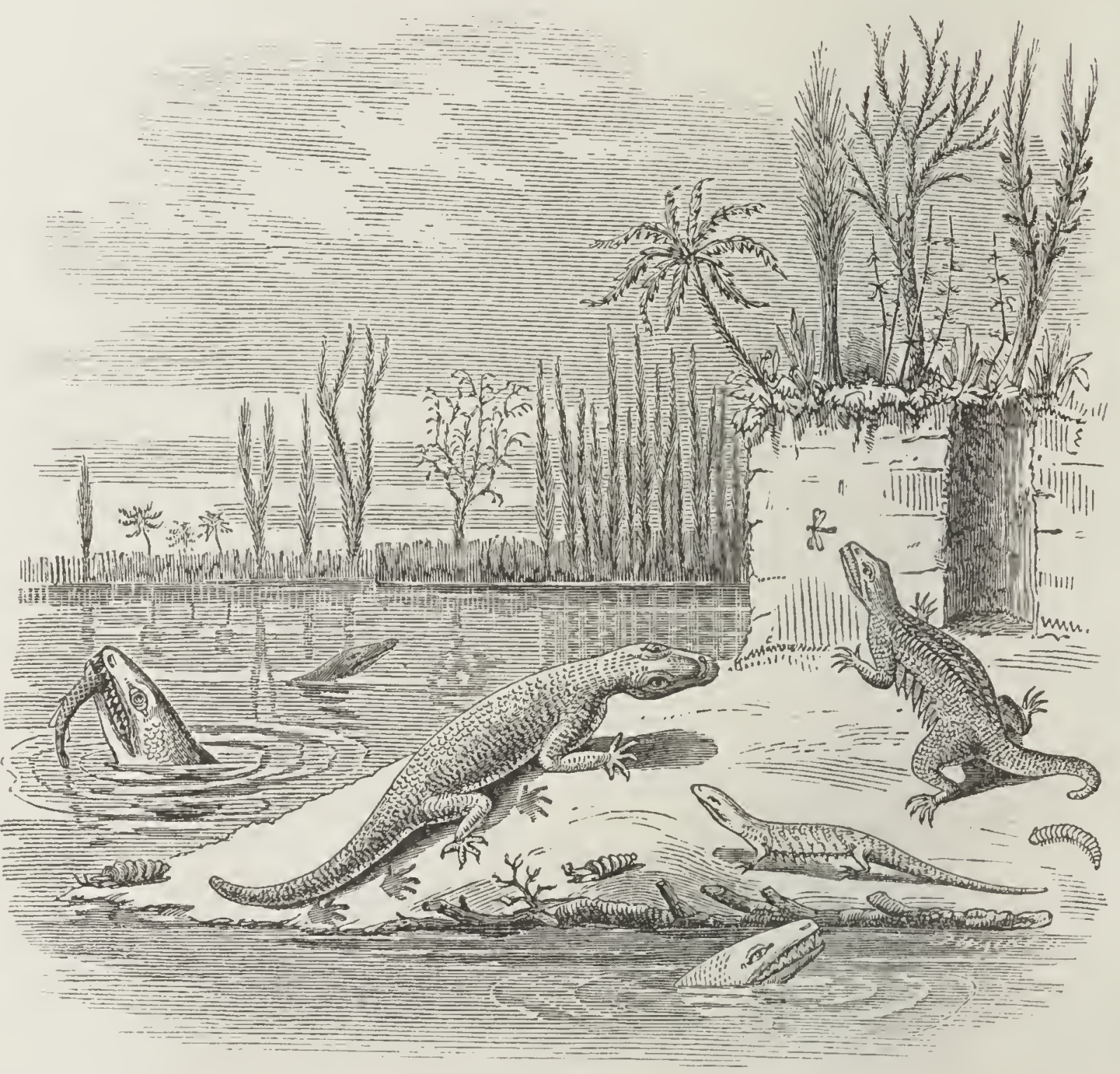

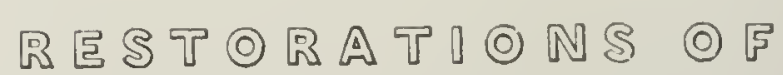

员A

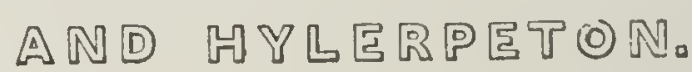




\section{A IR-BREATHERS}

OF THE

\section{COAL PERIOD :}

A DESCRTPTIVE ACCOUNT: OF THE REMAINS OF LAND ANTMATS FOUND IN THE COAL EORMATION

OF

\section{NOVA SCOTIA,}

TVTR REMARLS ON TIEJR REARING ON THEORTES OF THE FORMATION OT COAL, AND OF THE ORIGIN OF SPECIE.

BY J. W. DAWSON, LT.D., F.R.S., F.G.S., ETC., Drincipal of 3toceill anibersilm.

WITH ILLUSTRATIONS.

attontienl:

DAISSON BROTHERS, GREAT ST. JAMES STREET, LONDON, H. BALLLTERT; NEW YORE, BATLLIERE BROTHERS.

1863 , 



\section{CONTENTS.}

PAges.

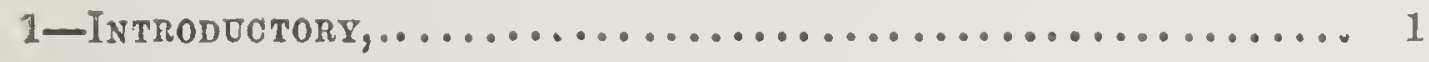

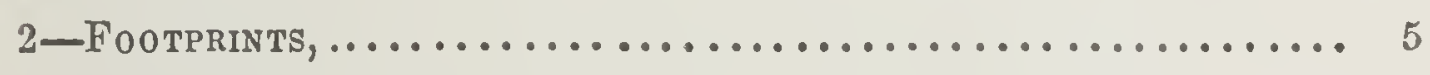

3-Baphetes Planiceps, ......................... 10

4-Dendrerpeton Acadiandm,................... 17

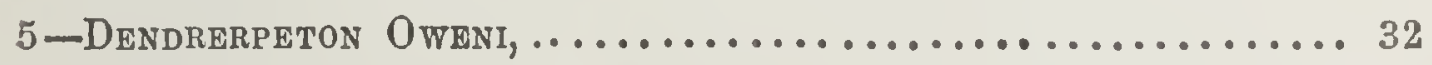

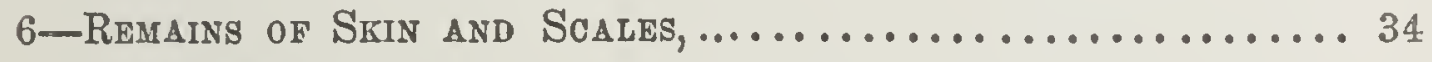

7 -Hylonomes Lrelli, ........................ 40

8-Hrlonomus Aciedendatus,...................... 49

9 -HrLonomos WrMan, $\ldots \ldots \ldots \ldots \ldots \ldots \ldots \ldots \ldots \ldots \ldots \ldots \ldots . \ldots \ldots$

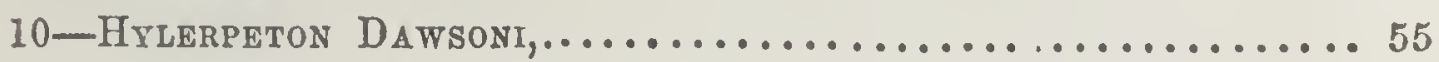

11-0ther Reptilian Remains,................... 58

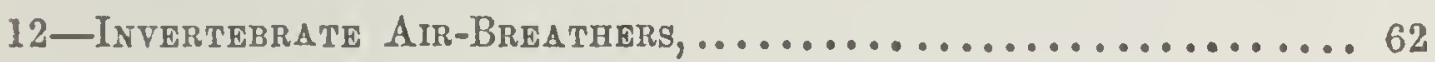

13-Characters of the Animals described, ............. 65

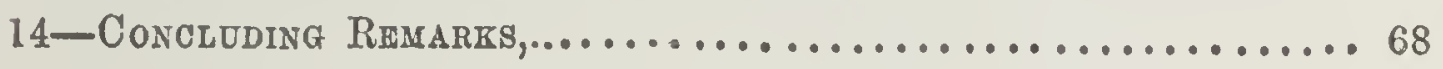


Digitized by the Internet Archive in 2020 with funding from University of Toronto 


\section{PREFACE.}

A certain moral obligation rests on the discoverer or possessor of new and valuable fossils, to make them known as extensively as possible to the scientific world. This he may do either personally or by the aid of others more conversant with the class of objects in question. I have generally preferred the latter course for all objects not included in my own special lines of investigation; and in the case of the subjects of the present brochure, have presented them, as discovered, to the investigation of naturalists specially engaged in the study of such remains. Through their kindness my specimens have been extensively illustrated, chiefly in the pages of the Journal of the Geological Society of London. I have, however, found it impossible to bring out in this way all the details desirable, and to present a connected view of the facts. Hence the present publication, in which I give a summary of all that I have been able to ascertain of the land animals of the coal period in Nova Scotia, and endeavour to make my collection of their fossil remains the common property of all geologists and naturalists, thereby discharging the obligations under which I am laid by having had these precious relics placed by Providence in my hands. 
To do this has cost me some sacrifice. The time required has been snatched from scanty intervals of rest in the midst of daily severe toil, and above all it has necessarily been taken from the prosecution of those researches in the fossil botany of the palæozoic period, to which I have devoted special attention for many years, and which are yet very incomplete. These circumstances, and the scanty means of reference and comparison at my disposal, I must plead as excuses for any imperfections which may appear in the work.

The lithographed illustrations must not be taken as evidence of the state of art in Canada. They are merely transfers from my own rough tracings of the objects, and the only merit which they claim is that of accuracy of outline.

The photograph inserted in some of the copies, I owe to the kindness of Mr. G. R. Prowse, an amateur artist of this city. It presents an accurate magnified picture of some of the principal remains; and deserves much praise as a highly successful application of microscopic photography to very difficult objects.

It is proper to add that the greater part of the matter of this memoir has appeared in the Canadian Naturalist and Geologist for 1863.

\section{J. W. DAWSON.}

McGill University, Montreal,

Jnne, 1863. 


\title{
THE AIR-BREATHERS
}

OF THE

\author{
COAL PERIOD
}

IN

\section{NOVA SCOTIA.}

\section{INTRODUCTORT.}

The animal population of the earth during the older or palæozoic period of its geological history, is known to us chiefly through the medium of remains preserved in rocks deposited in the bed of the ocean. In such rocks we have little reason to expect an abundant representation of the animals of the land, even if these existed at the time plentifully on the neighbouring shores. Perhaps for this reason,-perhaps because there were then no land animals, the organic remains of the Cambrian, Silurian, and Lower Devonian rocks consist, in so far as animal life is concerned, solely of marine species. In the Upper Silurian and Lower Devonian, however, land plants begin to appear; and in the Upper Devonian these are so numerous and varied as to afford a probability that animals also tenanted the land. Indeed, Mr. Hartt, of St. John, has just announced the discovery of remains, which he believes to be attributable to insects, in the rich plant-bearing Upper Devonian beds of that locality.* It is true also that reptiles of

* In a letter to the author. It is to be hoped that descriptions of these interesting remains may soon be published. 
high organization have been found in beds referred to the Upper Devonian, at Elgin, in Scotland; but so much doubt rests on the age of these beds, that it is unsafe at present to regard them as affording evidence of reptilian life at so early a period.

That there was dry land, even in the Lower Silurian period, we know, and can even trace its former shores. In Canada our old Laurentian coast extends for more than a thousand miles, from Labrador to Lake Superior, marking the southern border of the nucleus of the American continent in the Lower Silurian period. Along a great part of this ancient coast we have the sand-flats of the Potsdam Sandstone, affording very favorable conditions for the imbedding of land animals; did these exist ; still, notwithstanding the zealous explorations of the Geological Survey, and of many amateurs, no trace of an air-breather has been found. I have myself followed the Lower Silurian beds up to their ancient limits in some localities, and collected the shells which the waves had dashed on the beach, and have seen under the Silurian beds, the Laurentian rocks pitted and indented with weather marks, showing that this old shore was then gradually subsiding; yet the record of the rocks was totally silent as to the animals that may have trod the shore, or the trees that may have waved over it. All that can bo said is that the sun shone, the rain fell, and the wind blew as it does now, and that the sea abounded in living creatures. The ejes of trilobites, the weathered Laurentian rocks, the wind-ripples in the Potsdam sandstone, the rich fossils of the limestones, testify to these things. The existence of such conditions would lead us to hope that land animals may yet be found in these older formations. On the other hand, the gradual failure of one form of life after another, as we descend in the geological series, and the absence of fishes and land plants in the older Silurian rocks, might induce us to believe that we have here reached the beginning of animal life, and have left far behind us those forms that inhabit the land.

Even in the Carboniferous period, though land plants abound, air-breathers are few, and most of them have only been recently 
recognized. We know, however, with certainty that the dark and luxuriant forests of the coal period were not destitute of animal life. Reptiles crept under their shade, land-snails and millipedes fed on the rank leaves and decaying vegetable matter, and insects flitted through the air of the sunnier spots. Great interest attaches to these creatures; perhaps the first-born species in some of their respective types, and certainly belonging to one of the oldest land faunas, and presenting prototypes of future forms equally interesting to the geologist and the zoologist.

It has happened to the writer of these pages to have had some sbare in the discovery of several of these ancient animals. The coal formation of Nova Scotia, so full in its development, so rich in fossil remains, and so well exposed in coast cliffs, has afforded admirable opportunities for such discoveries, which have been so far improved that at least eight out of the not very large number of known Carboniferous land animals, have been obtained from it.* The descriptions of these creatures, found at various times and at various places, are scattered through papers ranging in date from 1844 to $1862, \dagger$ and are too fragmentary to give complete information respecting the structures of the animals, and their conditions of existence. I have, for some time, designed to prepare a resume of the published facts, with the addition of such new points as may arise from the further study of the specimens, but have been deterred by the incomplete state of my knowledge, and the prospect of further discoveries. So much has, however, now been done, and so many difficulties have been removed by the labours of several eminent naturalists who have examined the specimens, that I think the time has arrived when such a work may be undertaken with advantage to science.

* It appears that five species of Carboniferous reptiles have been recognised on the continent of Europe, three in Great Britain, and four in the United States. More full references will be made to these in the sequel.

I Papers by Lyell, Owen, and the author, in the Journal of the Geological Society of London, vols. i, ii, ix, $x, x i, x v i, x v i i, x v i i i$. 
In now endeavouring more fully to introduce the tenants of the coal forests of Nova Scotia to the notice of geologists and of the general reader, I shall take them nearly in the order in which they have become known to me, and shall not scruple to indulge in some gossip as to the circumstances of their discovery, and in some speculations as to their modes of life. I shall however endeavor carefully to sum up the facts ascertained as to their structure, and their relation to other creatures, whether their contemporaries or successors. 


\section{Footprints.}

Plate I.

It has often happened to geologists, as to other explorers of new regions, that footprints on the sand have guided them to the inhabitants of unknown lands. The first trace ever observed of reptiles in the carboniferous system, consisted of a series of small but well-marked footprints found by Sir W. E. Logan, in 1841, in the lower coal measures of Horton Bluff, in Nova Scotia; and as the authors of all our general works on geology have hitherto, in so far as I am aware, failed to do justice to this discovery, I shall notice it here in detail. In the year above mentioned, Sir William, then Mr.Logan, examined the coal fields of Pennsylvania and Nova Scotia, with the view of studying their structure, and extending the application of the discoveries as to Stigmaria underclays which he had made in the Welsh coal fields. On his return to England, he read a paper on these subjects before the Geological Society of London, in which he noticed the discovery of reptilian footprints at Horton Bluff. The specimen was exhibited at the meeting of the Society, and was, I believe, admitted on the high authority of Prof. Owen, to be probably reptilian. Unfortunately, Sir Williarn's paper appeared only in abstract in the Transactions; and in this abstract, though the footprints are mentioned, no opinion is expressed as to their nature. Sir William's own opinion is thus stated in a letter to me, dated June, 1843, when he was on his way to Canada, to commence the survey which has since developed so astonishing a mass of geological facts.

"Among the specimens which I carried from Horton Bluff, one is of very high interest. It exhihits the footprints of some reptilian animal. Owen has no doubt of the marks being genuine footprints. The rocks of Horton Bluff are below the gypsum of that neighbourhood; so that the specimen in question (if Lyell's views are 
correct*) comes from the very bottom of the coal series, or at any rate very low down in it, and demonstrates the existence of reptile at an earlier epoch than has hitherto been determined; none having been previously found below the magnesian limestone, or to give it Murchison's new name, the 'Permian era.'"

This extract is of interest, not merely as an item of evidence in relation to the matter now in hand, but as a mark in the progress of geological investigation. For the reasons above stated, the important discovery thus made in 1841 , and published in 1842, was overlooked; and the discovery of reptilian bones by Von Dechen, at Saarbruck, in 1844, and that of footprints by Dr. King in the same year, in Pennsylvania, have been uniformily referred to as the first observations of this kind. This error I now desire to correct, not merely in the interest of truth, but also in that of my friend Sir William Logan, and of my native province of Nova Scotia; and I trust that henceforth the received statement will be, that the first indications of the existence of reptiles in the coal period, were obtained by Logan, in the lower coal formation of Nova Scotia, in 1841. Insects and arachnidans, it may be observed, had previously been discovered in the coal formation in Europe.

The original specimen of these footprints is still in the collection of Sir William Logan. It is a slab of dark colored sandstone, glazed with fine clay on the surface; and having a series of seven footprints in two rows, distant about 3 inches; the distance of the impressions in each row being 3 or 4 inches, and the individual impressions about 1 inch in length. They seem to have been made by the points of the toes, which must have been armed with strong and apparently blunt claws, and appear as if either the surface had been somewhat firm, or as if the body of the animal had been partly water-borne. In one place only is there a distinct mark of the whole foot, as if the animal had exerted an unusual pressure

* Sir Charles Ljell bad then just read a paper announcing his discovery that the gypsiferous system of Nova Scotia is Lower Carboniferous, in which he mentions the footprints referred to, as being reptilian. 
in turning or stopping suddenly. One pair of feet, the fore feet I presume, appear to have had four claws; the other pair may havo had three or four, and it is to be observed that the outer toe, as in the larger footprints discovered by Dr. King, projects in the manner of a thumb, as in the chcirotherian tracks of the Trias. No mark of the tail or belly appears. The impressions are such as may have been made by some of the reptiles to be described in the sequel, as, for instance, by Dendrerpeton Acadianum.

Attention having been directed to such marks by these observations of Sir William Logan, several other discoveries of the same kind were subsequently made, in various parts of the province, and in different members of the carboniferous system. The first of these, in order of time, was made in 1844, in beds of red sandstone and shale near Tatamagouche, in the eastern part of Nova Scotia, and belonging to the upper or newer members of the coal measures. In examining these beds with the view of determining their precise geological age, I found on the surface of some of them impressions of worm-burrows, rain drops, and suncracks, and with these, two kinds of footprints, probably of reptilian animals. One kind consisted of marks, or rather scratches, as of three toes, and resembling somewhat the scratches made by the claws of a tortoise in creeping up a bank of stiff clay; they were probably of the same nature and origin with those found by Logan at Horton. The others were of very different appearance. They consisted of two series of strongly marked elongated impressions, without distinct marks of toes, in series four inches distant from each other, and with an intervening tail mark. They seem to have been produced by an animal wading in soft mud, so that deep holes, rather than regular impressions, marked its footsteps, and that in the bind foot, the heel touched the surface, giving a plantigrade appearance to the tracks. Rain marks had been impressed on the surface after the animal had passed over it, and these had probably aided in obliterating the finer parts of the impressions. These observations were published in the Journal of the Geological Society of London, vols. 1st and 2nd. 
Shortly afterward, Dr. Harding, of Windsor, when examining a cargo of sandstone which had been landed at that place from Parrsboro', found on one of the slabs a very distinct series of footprints each with four toes, and a trace of the fifth. Dr. Harding's specimen is now in the museum of King's College, Windsor. Its impreseions are more distinct, but not very different otherwise from those above described as found at Horton Bluff. The rocks at that place are probably of nearly the same age with those of Parrsboro'. I afterward examined the place from which this slab had been quarried, and satisfied myself that the beds are Carboniferous, and probably Lower Carboniferous. They were ripplemarked and sun-cracked, and I thought I could detect trifid footprints, though more obscure than those in Dr. Harding's slab. Similar footprints are also stated to have been found by Dr. Gesner, at Parrsboro'.

I have since observed several instances of such impressions at the Joggins, at Horton, and near Windsor, showing that they are by no meais rare, and that reptilian animals existed in no inconsiderable numbers throughout the coal-field of Nova Scotia, and from the beginning to the end of the carboniferous period. Two of the more interesting examples are figured with those already described. On comparing these with one another, it will be observed that Logan's, Harding's, and one of mine are of similar general character, and may have been made by one kind of animal, which must have had the fore and hind feet nearly of equal size. The other belongs to a smaller animal, which probably travelled on longer limbs, more in the manner of an ordinary quadruped. Its toes cannot be distinguished. On the whole, these footprints, while differing from those found by Dr. King in Pennsylvania, do not prove the existence of any kind of animal distinct from those to be described in the sequel, and known to us by the preservation of portions of their skeletons.

The study of these footprints shows that the animals which produced them may, in certain circumstances, have left impressions of only two or three of their toes, while in other cir- 
cumstances all may have left marks; and that, when wading in deep mud, their footprints were altogether different from those made on hard sand or clay. In some instances the impressions may have been made by animals wading or swimming in water, while in others the rain-marks and sun-cracks afford evidence that the surface was a sub-aerial one. They are chiefly interesting as indicating the wide diffusion and abundance of the creatures producing them, and that they haunted tidal flats and muddy shores, perhaps emerging from the water that they might bask in the sun, or possibly searching for food among the rejectamenta of the sea, or of lagunes and estuaries.

\section{EXPLANATION OF PLATE I.}

Footprints of Reptiles, \&c.

Fig. 1.-Footprints discovered by Sir W. E. Logan, in the Lower Carboniferous beds of Horton Bluff, in 1841 ; reduced to onefourth of the natural size. (1a) one of the impressions, natural size.

"2. Footprints discorered by Dr. Harding, in the Lower Carboniferous beds of Parrsboro'; one-fourth of the natural size. (2a) Prints of fore and hind foot natural size. This figure is from a rubbing kindly taken for me by Prof. How, of Windsor.

"3.-Footprints from the Coal Measures of the South Joggins; one-fourth natural size. (3a) One of the impressions natural size.

"4.-Smaller footprints from the South Joggins; one-fourth natural size.

"5.-Skin of a reptile, found with remains of a small Dendrerpeton, in an erect tree at the Joggins. (a) Scaly portions; (b) Traces of hind leg? and small scales. (c) (d) Portions magnified, showing scales. 


\section{BAPHETES PLANICEPS.}

\section{Plate II.}

In the summer of 1851, I had occasion to spend a day at the Albion mines; and on arriving at the railway station in the afternoon, found myself somewhat too early for the train. By way of improving the time thus left on my hands, I betook myself to the examination of a large pile of rubbish, consisting of shale and ironstone from one of the pits, and in which I had previously found scales and tecth of fishes. In the blocks of hard carbonaceous shale and earthy coal, of which the pile chiefly consisted, scales, teeth and coprolites often appeared on the weathered ends and surfaces as whitish spots. In looking for these, I observed one of much greater size than usual, on the edge of a block, and on splitting it open, found a large flattened skull, the cranial bones of which remained entire on one side of the mass, while the palate and teeth, in a more or less fragmentary state, came away with the other half. Carefully trimming the larger specimen, and gathering all the smaller fragments, I packed them up as safely as possible, and returned from my little excursion much richer than I had hoped.

The specimen, on further examination, proved somewhat puzzling. I supposed it to be, most probably, the head of a large ganoid fish; but it seemed different from any thing of this kind with which I could compare it ; and at a distance from comparative anatomists, and without sufficient means of determination, I dared not refer it to anything higher in the animal scale. Hoping for further light, I packed it up with some other specimens, and sent it to the Secretary of the Geological Society of London, with an explanatory note as to its geological position, and requesting that it might be submitted to some competent osteologist for examination. For a year or two however, it remained as quietly 
in the Society's collection as if in its original bed in the coal mine, until attention having been attracted to such remains by the discoveries made by Sir Charles Lyell and myself in 1852, at the South Joggins, and published in $1853,{ }^{*}$ the Secretary or President of the Society re-discovered the specimen, and handed it to Prof. Owen, by whom it was described in Dec., $1853, \dagger$ under the name of Baphetes planiceps, which may be interpreted the "flat-headeddiving animal," in allusion to the flatness of the creature's skull, and the possibility that it may have been in the habit of diving.

The parts preserved in my specimen are the bones of the anterior and upper part of the skull in one fragment, and the teeth and palatal bones in others. With respect to the former, Prof. Owen recognizes in it the premaxillary (p.) (Fig. 1) and maxillary bones, $(m$.$) both presenting traces of the sockets of teeth, which$ appear to be in a single series; but other fragments show that in part at least, they were in double series. The central portion of the skull and part of the orbits are made up of the nasals, (n.) the frontal ( $\mathrm{fr}$.) and the prefrontal (pf.) in a manner characteristic of the Labyrinthodont reptiles, and not of fishes. The upper surface of the bone, seen in some detached fragments, as in Fig. 4, has a pitted surface, like that of the stone of a peach, as is the case also in the Labyrinthodonts. In sections under the microscope, the bone shows vascular canals and small rounded bone-cells, a structure observed in Labyrinthodon, and in some of the larger Saurians (Figs. 2 and 8). The teeth are conical, and somewhat curved, the outer series from a line to two lines in diameter, and the inner series three lines or more (Figs. 3 and 5). They are implanted in shallow sockets in the maxillary and premaxillary bones, and are anchylosed to the sockets. For the lower third, the outer surface presents shallow vertical grooves, conformably with the plicated character of the internal structure (Figs. 3, 7, and 10). The upper portion is smooth, and its internal structure presents

* Journal of Geological Socicty of London, vol. ix.

f Journal of Gcological Socicty, vol. $x$; and additional notes, vol. xi. 
merely radiating tubes of ivory, and concentric layers, (Figs.s. 3, 6 , and 9 ). The whole of these characters are regarded as allying the animal with the great crocodilian frogs of the Trias of Europe, first known as Cheirotherians, owing to the remarkable hand-like impressions of their feet, and afterwards as Labyrinthodonts, from the beautifully complicated convolutions of the ivory of their teeth.

The only additional remains attributable to this creature, found since the publication of Professor Owen's description, are the bone represented in Fig. 12, and the scute or scale represented in Fig. 11. The former may be a scapular or sternal bone, and, if so, would warrant the belief that the creature possessed anterior limbs of considerable size; the proportion relatively to the skull being much the same as in the American bullfrog. The latter is marked in the same way as the bones of the head, and would indicate that Baphetes was protected by bony dermal scales, resembling those of the crocodile.

There is one point illustrated by the bone represented in Fig. 12, to which I would earnestly invite the attention of comparative anatomists. It is the distortion to which bones are subjected when imbedded in soft deposits, especially those containing vegetable matter. In modern peat bogs, skulls have been found nearly as pliable as leather, owing to the partial removal of their phosphate of lime; and in clay beds they are often found softer than chalk, from the removal of their animal matter. Human skulls, buried under no great weight of earth, have often been strangely distorted from this posthumous softening. Even teeth are affected in this way. In the remains of the old Indian village of Hochelaga, at Montreal, while the teeth of bears are found in the drier and more sandy soil quite perfect and unaltered; in damp places, and where they are imbedded in organic matter thrown out from the cabins, they are softened, so that a large canine may be easily compressed between the finger and thumb. Changes of this kind have no doubt been experienced by all the bones imbedded in coal, carbonaceous shale, and similar deposits; and in the great compression which the mass has ex- 
perienced, the bones, yielding with it, have been flattened and distorted in the most remarkable manner. In the bones, in short, as in the plants of the coal, the flattened specimen must not be accepted as representing the original form. The bone represented in Fig. 12, for example, must have been strong, and nearly cylindrical in its middle portion, and much curved; but it has given way to pressure, and has as it were been faulted along certain lines, so as to lose almost entirely its original relief. The sectional view in Fig. 13, represents some of these faults, with the present profile of the bone, its original outline being represented by the dotted line. The title of the present species to the specific name planiceps, is also in part dependent on this cause. No doubt its head, like that of other batrachians, was somewhat flat, but this has been much increased by pressure; in so much that the fragments of the specimen show that the palate is almost brought into contact with the roof of the skull, and that scarcely a quarter of an inch is left in some places for the depth of the great orbits. The interior of the skull must have been filled with soft slime, and this has been compressed into a bard stone. In like manner, I shall have occasion to show, in reference to other reptiles of the coal, that their bones have been much altered in form, so that limb bones, which, when buried in a nearly erect position, show broad and flat articulating surfaces, have these compressed into mere edges, when the specimens lie horizontally, and that hollow bones have been fractured longitudinally, and pressed almost perfectly flat. Anatomists may be very easily misled by such appearances, and should carefully enquire as to the possibility of their occurrence, before deducing inferences from the forms of bones.

Of the general form and dimensions of Baphetes, the facts at present known, do not enable us to say much. Its formidable teeth and strong maxillary bones show that it must have devoured animals of considerable size, probably the fishes whose remains. are found with it, or the smaller reptiles of the coal. It must in short have been crocodilian, rather than frog-like, in its mode of 
life ; but whether, like the labyrinthodonts, it had strong limbs and a short body, or like the crocodiles, an elongated form and a powerful natatory tail, the remains do not decide. One of the limbs, or, a vertebra of the tail would settle this question, but neither have as yet been found. That there were large animals of the labyrinthodontal form in the coal period, is proved by the footprints discovered by Dr. King in Pennsylvania, which may have been produced by an animal of the type of Baphetes. On the other hand that there were large swimming reptiles, seems established by the recent discovery of the vertebre of Eosaurus Acadianus, at the Joggins, by Mr. Marsh.* The locomotion of Baphetes must have been vigorous and rapid, but it may have been effected both on land and in water, and either by feet or tail, or both.

With the nature of its habitat we are better acquainted. The area of the Albion Mines coal field was somewhat exceptional in its character. It seems to have been a bay or indentation in the Silurian land, separated from the remainder of the coal-field by a high shingle beach, now a bed of conglomerate. Owing to this circumstance, while in the oilher portions of the Nova Scotia coalfield, the beds of coal are thin, and alternate with sandstones and shales, at the Albion Mines a vast thickness of almost unmixed vegetable matter has been deposited, constituting the 'main seam' of thirty-eight feet thick, and ihe 'deep seam' twenty-four feet thick, as well as still thicker beds of highly carbonaceous shale. But, though the area of ihe Albion coal measures was thus separated, and preserved from marine incursions, it must have been often submerged, and probably had connection with the sea, through rivers or channels cuiting the enclosing beach. Hence beds of earthy matter occur in it, containing remains of large fishes. One of the most important of these is that known as the "Holing stone," a band of black lighly carbonaceous shale, coaly matter, and clay ironstone, occurring in the main seam, about five feet below its roof, and varying in thickness from two inches to nearly two feet.

* Silliman's Journal, 1859. 
It was from this band, that the rubbish-heap, in which I found the skull of Baphetes planiceps, was derived. It is a laminated bed, sometimes hard and containing much ironstone, in other places soft and shaly : but always black and carbonaceous, and often with layers of coarse coal, though with few fossil plants retaining their forms. It contains large round flat scales and flattened curved teeth, which I attribute to a fish of the genus Rhizodus, resembling, if not identical with, $R$. lancifer, Newberry. With these are double pointed shark-like teeth, and long cylindrical spines of a species of Diplodus, which I have named $D$. acinaces $\dagger$ There are also shells of the minute Spirorbis, so common in the coal measures of other parts of Nova Scotia, and abundance of fragments of coprolitic mailer. I have also observed in it a few scales having the peculiar one-sided form of those of Archegosaurus and Dendrerpeton; and which I may possibly describe and figure, among miscellaneous indications of unknown creatures, in the end of this memoir.

It is evident that the "Holing stone" indicates one of those periods in which the Albion coal area, or a large part of it, was under water, probably fresh or brackish, as there are no properly marine shells in this, or any of the other beds of this coal series. We may then imagine a large lake or lagune, loaded with trunks of trees and decaying vegeiable matter, having in its shallow parts, and along its sides, dense brakes of Calamites, and forests of Sigil- laria, Lepidodendron, and other trees of the period, extending far on every side as damp pestilential swamps. In such a habitat, uninviting to us, but no doubt suited to Baphetes, that creature crawled through swamps and thickets, wallowed in flats of black mud, or swam and dived in search of its finny prey. It was, in so far as we know, the monarch of these swamps, though there is evidence of the existence of similar creatures of this type quite as large in other parts of the Nova Scotia coal field; but my notice of these I defer for the present, in hope that additional facts may

† Supplement to Acadian Geology, pp. 43 and 50. 
be discovered in respect to them. If this should not be the case, they will be noticed among miscellaneous remains in the sequel.

\section{EXPLANATION OF PLATE II.}

\section{Baphetes planiceps.}

Fig. 1. - Skull seen from below, half natural size.

"2.-Portion of bone of skull magnified, to show vascular canals and bone-cells.

“ 3.-One of the largest teeth, natural size.

"4.-Sculpturing of skull, and margin of orbit, natural size.

"5.-Fragment of maxillary bone, with four teeth of the outer series, and one of the inner large teeth,- - the points of the teeth restored from fragments in other specimens.

" 6 and 7.--Sections of a tooth magnified: 6 , upper part; 7 , lower part, with convoluted dentine.

"8. -Section of bone in Fig. 2, more highly magnified.

" 9 and 10.-Sections of tooth represented in Figs. 6 and 7, natural size.

"11.-Dermal scale found with remains of Baphetes.

"12.-Scapular or sternal bone found with remains of Baphetes.

"13.-Longitudinal section of the middle of the same, showing the manner in which it has been crushed. 


\section{IV.-Dendrerpeton Acadianum.}

Plate III.

The geology of Nova Scotia is largely indebted to Sir Charles Lyell. Though much had previously been done by others, his personal explorations in 1842 , and his paper on the gypsiferous formation, published in the following year, first gave form and shape to some of the more difficult features of the geo$\log y$ of the country, and brought it into relation with that of other parts of the world. In geological investigation, as in many other things, patient plodding may accumulate large stores of fact, but the magic wand of genius is required to bring out the true value and significance of these stores of knowledge. It is scarcely too much to say that the explorations of $\dot{a}$ few weeks, and subsequent study of the subject by Sir Charles, with the impulse and guidance given to the labors of others, did as much for Nova Scotia, as might have been effected by years of laborious work under less competent heads.

Sir Charles naturally continued to take an interest in the geology of Nova Scotia, and to entertain a desire to explore more fully some of those magnificent coast sections which he had but hastily examined; and when, in 1851, he had occasion to revisit the United States, he made an appointment with the writer of these pages to spend a few days in renewed explorations of the cliffs of the South Joggins. The object specially in view was the thorough examination of the beds of the true coal measures, with reference to their contained fossils, and the conditions of accumulation of the coal; and the results were given to the world in a joint paper on "The remains of a reptile and a land-shell discovered in the interior of an erect tree in the coal measures of Nova Scotia," and in the writer's paper on the "Coal Measures of the South Joggins ;"* while other important investigations grew out of the following up of these

* Journal of the Geological Society of London; Vols. ix and $x$; and Acadian Geology. 
researches, and much matter in relation to the vegetable fossils still remains to be worked up. It is with the more striking fact of the discovery of the remains of a reptile in the coal measures that we have now to do.

The South Joggins Section is, among other things, remarkable for the number of beds which contain remainso erect trees imbedded in situ: these trees are for the most part Sigillarix, varying in diameter from six inches to five feet. They have grown in underclays and wet soils, similar to those in which the coal was accumulated; and these having been submerged or buried by mud carried down by inundations, the trees, killed by the accumulations around their stems, have decayed, and their tops being broken off at the level of the mud or sand, the cylindrical cavities, left open by the disappearance of the wood, and preserved in their form by the greater durability of the bark, have been filled with sand and clay. This, now hardened into stone, constitutes pillar-like casts of the trees, which may often be seen exposed in the cliffs, and which, as these waste away, fall upon the beach. The sandstones enveloping these pillared trunks of the ancient Sigillarix of the coal, are laminated or bedded, and the laminæ, when exposed, split apart with the weather, so that the trees themselves become split across; this being often aided by the arrangement of the matter within the trunks, in layers more or less corresponding to those without. Thus one of these fossil trees usually falls to the beach in a series of discs, somewhat resembling the grindstones which are extensively manufactured on the coast. The surfaces of these fragments often exhibit remains of plants which have been washed into the hollow trunks and have been imbedded there; and in our explorations of the shore, we always carefully scrutinized such specimens, both with the view of observing whether they retained the superficial markings of Sigillarix, and with reference to the fossils contained in them. It was while examining a pile of these "fossil grindstones," that we were surprised by finding on one of them what seemed to be fragments of bone. On careful search other bones appeared, and they had the 
aspect, not of remains of fishes, of which many species are found fossil in these coal mcasures, but rather of limb-bones of a quadruped. The fallen pieces of the tree were carefully taken up, and other bones disengaged, and at length a jaw with teeth made its appearance. We felt quite confident, from the first, that these bones were reptilian; and the whole, being carefully packed and labelled, were taken by Sir Charles to the United States, and sub. mitted to Prof. J. Wyman of Cambridge ; who recognized their reptilian character, and prepared descriptive notes of the principal bones, which appeared to have belonged to two species. He also observed among the fragments an object of different character, apparently a shell ; which was recognized by Dr. Gould of Boston, and subsequently by Mr. Deshayes, as probably a land-snail, and has since been named Pupa vetusta.

The specimens werc subsequently taken to London and re-examined by Prof. Owen, who confirmed Wyman's inferences, added other characters to the description, and named the larger and better preserved species Dendrerpeton Acadianum, in allusion to its discovery in the interior of a tree, and to its native country of Acadia or Nova Scotia. With the aid of Plate III, I shall now endeavour to describe this species as fully as the materials at my command will allow, and shall then make some remarks on its affinities, habitat, and mode of life. It is necessary to state in explanation of the fragmentary character of the remains represented in the plate, that in the decay of the animals imbedded in the erect trees at the Joggins, their skeletons have become disarticulated, and the portions scattered, either by falling into the interstices of the vegetable fragments in the bottom of the hollow trunks, or by the water with which these may have sometimes been partly filled. We thus can obtain only separate bones; and though all of these are no doubt present in each case, it is impossible in breaking up the hard matrix to recover more than a small proportion of thcm. For this reason I have been obliged to have recourse, not merely to the original specimen whose discovery is noticed above, but to three others subscquently obtained by me; all however belong- 
ing, on the evidence of the teeth and more important bones, to one species, and all being nearly, though not absolutely, of the same size. It is also proper to state that in the case of the original specimen, and another still more perfect one, both of which are now in Londun, I have been able to refer only to the published plates, and $t_{0}$ add to these from parts of two additional individuals still in my own collection.

In form, Dendrerpeton Acadianum was probably lizard-like; with a broad flat head, short stout limbs and an elongated tail; and having its skin, and more particularly that of the belly, protected by small bony plates closely overlapping each other. It may have attained the length of two feet. The form of the head is not unlike that of Baphetes, but longer in proportion; and much resembles that of the labyrinthodont reptiles of the Trias (Fig. 1). The bones of the skull are sculptured as in Baphetes, but in a smaller pattern (Figs. 8, 9). The nostrils are small, and near the muzzle : the orbits are circular, and separated by a space of more than their own diameter. In the upper jaw there is a series of conical teeth on the maxillary and intermaxillary bones (Figs. 5, 15). Those on the intermaxillaries are much larger than the others, and have the aspect of tusks or canines (Figs. 3, 13). Within this outer series of teeth, but implanted apparently in the same bones, there is as in Archegosaurus a second series of teeth, closely placed, or with intervals equal to the diameter of one tooth. These inner teeth are longer than the others, implanted in shallow sockets, to which they are anchylosed, and have the dentine plicated, except toward the point (Figs. 2, 4, 6, 7, 17). A third group of teeth, blunt at the points, largely hollow in the interior, and with the dentine quite simple, appears in detached bones, which may represent the vomer (Fig. 12). Only a part of this formidable armature of teeth appears in the skull represented in Fig. 1, as the bones of the roof of the mouth have been removed, adhering to the opposite side of the matrix; but the fact of the occurrence of two sets of teeth was ascertained by Prof Wyman, from the original specimens, and is manifest in the fragment 
represented in Fig. 17; 'while the other teeth, supposed to bo vomerine, appear in fragments which must, from their size and collocation, have belonged to Dendrerpeton. It will be observed that all these teeth are anchylosed to the bone; and that those of the vomer are thinly walled and simple, the outer series on the maxillaries and intermaxillaries simple and flattened, while the inner series of teeth are conical and plicated. In the lower jaw there was a uniform series of conical teeth, not perceptibly enlarged toward the front; at least this is the case in the only specimen at present in my collection (Fig. 16); which is however merely an imperfect cast in hard sandstone.

The scapular and sternal bones seem to have been well developed and strong, but only portions of them are known (Fig. 25.) The fore limb of the adult animal, including the toes, must have been four or five inches in length, and is of massive proportions. The bones were hollow, and in the case of the phalanges the bony walls were thin, so that they are often found crushed flat. The humerus however was a strong bone, with thick walls and a cancellated structure toward its extremities; still even these have sometimes yielded to the great pressure to which they have been subjected. Fig. 26 shows the humerus of the original specimen of the species, and Fig. 10 exhibits a series of sections of a similar bone, probably the humerus of a smaller individual. The cavity of the interior of the limb-bones is usually filled with calc-spar stained with organic matter, but showing no structure; and the inner side of the bony wall is smooth, without any indication of cartilaginous matter lining it.

The vertebræ, in the external aspect of their bodies, remind one of those of fishes, expanding toward the extremities, and being deeply hollowed by conical cavities, which appear even to meet in the centre. There is however a large and flattened neural spine. The vertebræ are usually much crushed, and it is almost impossible to disengage them from the stone. Fig. 21 exhibits the usual form, and Fig. 22 another; which, in its long neural and hæmal spines, reminds us of the caudal vertebre of those batrachians and 
reptiles which have tails flattened for swimming, and probably indicates that this was the case with Dendrerpeton. Fig. 23 is a transverse section of a somewhat crushed vertebra, showing its ossified centrum and neural spine, and also the microscopic structure of the bone. The ribs are long and curved, with an expanded head, near to which they are solid, but become hollow toward the middle; and the distal extremities are flattened and thin walled. The posterior limb seems to have been not larger than the anterior, perhaps smaller. The bones represented in Fig. 27, which I refer to this member, probably belonged to a somewhat smaller individual than that to which the humerus in Fig. 26 belonged. The tibia is much flattenea at the extremity, as in some labyrinthodonts, and the foot must have been broad, and probably suited for swimming or walking on soft mud, or both. That the hind limb was adapted for walking is shown, not merely by the form of the bones, but also by that of the pelvis, the best preserved specimen of which is represented in Fig. 28 ; but an iliac bone of still larger size is figured in the Journal of the Geological Society, Vol. IX.

The external scales are thin, oblique-rhomboidal or elongatedoval, marked with slight concentric lines, but otherwise smooth, and having a thickened ridge or margin; in which they resemble those of Arckegosaurus, and also those of Pholidogaster pisciformis, recently described by Huxley from the Edinburgh coal-field,-an animal which indeed appears in most respects to have a close affinity with Dendrerpeton. The microscopic structure of the scales is quite similar to that of the other bones, and different from that of the scales of ganoid fishes, the shape of the cells being batrachian as in Fig. 11. Figs. 18 and 19 exhibit different forms of the scales.

With respect to the affinitics of the creature, $I$ think it is obvious that it presents some points of resemblance, on the one hand to Archegosaurus, and on the other, to Labyrinthodon; and that it has the same singular mixture of ichthyic, batrachian, and reptilian characters which distinguish these ancient animals, and which give them the appearance of prototypes of the reptilian 
class. Professor Owen regards Archegosaurus as the type of the order Ganocephala, which he characterizes as having the head protected by sculptured and polished ganoid plates, no occipital condyles, teeth with converging folds of cement at their basal half, the notochord persistent, the ribs short and straight, the limbs natatory and small; and holds that Dendrerpeton approaches more nearly to this order than to the Labyrinthodonts. But at the time when this opinion was expressed, he was not fully aware of the development of the limbs and ribs, and of the ossified condition of the vertebræ; characters which, with the form of the skull, the arrangement of the teeth, and the probable possession of occipital condyles, appear to determine the scale in favour of the Labyrinthodonts. At the same time it must be admitted that Dendrerpeton is far removed from the typical genus Labyrinthodon, and that in the characters in which it differs, it leans toward Archegosaurus; closely resembling in thisits contemporary Pholidogaster pisciformis already referred to.

This ancient inhabitant of the coal swamps of Nova Scotia, was, in short, as we often find to be the case with the earliest forms of life, the possessor of powers and structures not usually, in the modern world, combined in a single species. It was certainly not a fish, yet its bony scales, and the form of its vertebræ, and of its teeth, might, in the absence of other evidence, cause it to be mistaken for one. We call it a batrachian, yet its dentition, the sculpturing of the bones of its skull, which were certainly no more external plates than the similar bones of a crocodile, its ribs, and the structure of its limbs, remind us of the higher reptiles; and we do not know that it ever possessed gills, or passed through a larval or fish-like condition. Still, in a great many important characters, its structures are undoubtedly batrachian. It stands, in short, in the same position with the Lepidodendra and Sigillarice under whose shade it crept, which though placed by palæo-botanists in alliance with certain modern groups of plants, manifestly differed from these in many of their characters, and occupied a different position in nature. In the coal period, the distinctions of 
physical and vital conditions were not well defined-dry land and water, terrestrial and aquatic plants and animals, and lower and higher forms of animal and vegetable life, are consequently not easily separated from each other. This is no doubt a state of things characteristic of the earlier stages of the earth's history, yet not necessarily so ; for there are some reasons, derived from fossil plants, for believing that in the preceding Devonian period there was less of this, and consequently that there may then have been a higher and more varied animal life than in the coal period.* Even in the modern world also, we still find local cases of this early union of dissimilar conditions. It is in the swamps of Africa, at one time dry, at another inundated, that such intermediate forms as Lepidosiren occur, to baffle the classificatory powers of naturalists; and it is in the stagnant unaerated waters, half swamp, half lake or river, and unfit for ordinary fishes, that the semi-reptilian Amia and Lepidosteus still keep up the characters of their palæozoic predecessors.

The dentition of Dendrerpeton shows it to have been carnivorous in a high degree. It may have captured fishes and smaller reptiles, either on land or in water, and very probably fed on dead carcases as well. If, as seems likely, the footprints referred to in a previous section belong to Dendrerpeton, it must have frequented the shores, either in search of garbage, or on its way to and from the waters. The occurrence of its remains in the stumps of Sigillaria, with land-snails and millipedes, shows also that it crept in the shade of the woods in search of food; and under the head of coprolitic matter, in a subsequent section, I shall show that remains of excrementitious substances, probably of this species, contain fragments attributable to smaller reptiles, and other animals of the land.

All the bones of Dendrerpeton hitherto found, as well as those of the smaller reptilian species hereafter described, have been ob-

* See the author's paper on Deronian plants, Journal of the Geological Society, Vol. xviii, p. 328. 
tained from the interior of erect Sigillarix, and all of these in one of the many beds, which, at the Joggins, contain such remains. The thick cellular inner bark of Sigillaria was very perishable; the slender woody axis was somewhat more durable; but near the surface of the stem, in large trunks, there was a layer of elongated cells, or bast tissue, of considerable durability, and the outer bark was exceedingly dense and indestructible.* Hence an erect tree, partly imbedded in sediment, and subjected to the influence of the weather, became a hollow shell of bark; in the bottom of which lay the decaying remains of the woody axis, and shreds of the fibrous bark. In ordinary circumstances such hollow stems would be almost immediately filled with silt and sand, deposited in the numerous inundations and subsidences of the coal swamps. Where however they remained open for a considerable time, they would constitute a series of pitfalls, into which animals walking on the surface might be precipitated; and being probably often partly covered by remains of prostrate trunks, or by vegetation growing around their mouths, they would be places of retreat and abode for land-snails and such creatures. When the surface was again inundated or submerged, all such animals, with the remains of those which had fallen into the deeper pits, would be imbedded in the sediment which would then fill up the holes. These seem to have been the precise conditions of the bed which has afforded all these remains. I may add that I believe all the trees, four or five in number, which have become exposed in this bed since its discovery, have been ransacked for such remains; and that while all have afforded some reward for the labour, some have been far more rich than others in their contents. It is also to be observed that owing to the mode of accumulation of the mass filling the trees, the bones are usually found scattered in every position, and those of different species intermingled; and that being often much more friable than the

* See a paper by the author, on the structures of coal; Journal of the Geological Society, Vol. xr; also supplement to Acadian Geology. 
matrix, much labour is required for their development; while after all has been done, the result is a congeries of fragments like that presented by Plate III. The two specimens which displayed the largest number of bones in juxtaposition, are one of Dendrerpeton Acadianum, and one of Hylonomus Lyelli, both presented by me to the geological Society of London, and now in its collection; but of which I shall endeavour to obtain accurate representations for this memoir.

In order more fully to illustrate the mode of occurence of these remains, I quote the following notice of my last explorations in the bed containing them, from the Journal of the Geological Society of London, for 1861 :

"In the bed which has bitherto alone afforded reptilian remains in its erect trees, two additional examples of these were exposed. One was on the beach, and in part removed by the sea. The other was in the cliff, but so far disengaged that a miner succeeded in bringing it down for me. In the first, comparatively little was found. It afforded only a few shells of Pupa vetusta, and scattered bones of a full-grown individual of Dendrerpeton Acadianum.

"The second tree was more richly stored; and, being in situ, was very instructive as to the mode of occurence of the remains. Like all the other trees in which reptilian bones have been found, it sprang immediately from the surface of the six-inch coal in Group XV. of my section*; which is also Coal No. 15 of Sir W. E. Logan's sectionf. Its diameter at the base was two feet, and its height six feet, above which, however, an appearance of additional height was given by the usual funnel-shaped sinking of the overlying beds toward the cavity of the trunk. The bark is well preserved in the state of bituminous coal, and presents externally a longitudinally wrinkled surface, without ribs or leaf-scars; but within, on the 'ligneous' surface, or that of the inner bark, there

* Quart. Journ. Geol. Soc. Vol. ix. p: 58, and Vol. x. p. 20.

$\dagger$ Reports of Geol. Survey of Canada, 1845. 
are broad flat ribs, and transversely elongated scars. The appearances are preciscly those which might be expected on an old trunk of my Sigillaria Brownii; to which species this tree may have very well belonged.t

"The contents of the trunk correspond with those of others previously found. At the bottom is the usual layer of mineral charcoal, consisting of the fallen wood and bark of the tree itself. Abore this, about two feet of its beight are filled with a confused mass of vegetable fragments, consisting of Cordaites, Lepidodendron, Ulodendron, Lepidostrobus, Calamites, Trigonocarpum, stipes and fronds of ferns, and mineral charcoal; the whole imbedded in a sandy paste blackened by coaly matter. In, and at the top of this mass occur the animal remains. The remainder of the trunk is occupied with grey and buff sandstone, containing a few fragments of plants, but no remains of animals.

"Portions of six reptilian skeletons were obtained fiom this trunk. The most important of these is a large and nearly complete skeleton of Dendrerpeton Acadianum.* Another specimen found in this trunk is a jaw of an animal about the size of Dendrerpeton Acadianum, but with fewel and larger teeth. $\dagger$ The remaining skeletons were imperfect, and belonged to a small individual of Dendrerpeton Acadianum, two of Hylonomus Lyelli, and one of Hylonomus Wymani. The dislocated condition of these and other skeletons is probably due to the circumstance that, when they were introduced, the matter filling the trunk was a loose mass of fragments, into the crevices of which the bones dropped, on decay of the soft parts. Most of the skeletons lie at the sides of the trunk, as if the animals had before death crept close to the walls of their prison. At the time when the reptiles were introduced, the hollow trunk must have been a pit four feet in depth.

$\ddagger$ Quart. Journ. Geol. Soc. Vol. xrii. p. 523.

* Now in the collection of the Geological Society of London. Fig. 1, represents the skull of this specimen.

f Since named and described by Prof. Owen as Hylerpeton Dawsoni 
A number of specimens of Pupa vetusta and Xylobius Sigillaria were found, but nothing throwing further light on these species.

"The beds on a level with the top of this erect tree are arenaceous sandstones, with numerous erect Calamites. I searched the surfaces of these beds in vain for bones or footprints of the reptiles which must have traversed them, and which, but for the hollow erect trees, would apparently have left no trace of their existence. On a surface of similar character, sixty feet higher, and separated by three coals, with their accompaniments, and a very thick compact sandstone, I observed a series of footprints, which may be those of Dendrerpeton or Hylonomus."

Through the kindness of the Council of the Geological Society of London, the fine skeleton of Dendrerpeton Acadianum, sent by me to the Society in 1861, has been returned for my inspection in the preparation of this article.

I am now able to state, in addition to the facts already noticed that the large furrowed teeth of the inner series were not placed in the palatal bones, but on the maxillaries and intermaxillaries, the outer series of smaller and simple teeth being borne on the outer margin of these bones. The arrangement was thus somewhat similar to that in Lepidosteus. Immediately within the large teeth were the vomerine series, which were very numerous and irregularly placed, but small, with the exception of a few in front. They extended backward in two lines along both sides of the palate, in this also resembling some ganoid fishes.

In this specimen, the lower jaw, remaining in place under the skull, is seen to contain, especially toward the front, long furrowed teeth like those of the upper jaw, implanted in round sockets on the broad upper surface of the mandible, with others more simple and of smaller size.

By carefully removing the stone, I have uncovered the occipital condyles, which are double and square in outline, much like those of Labyrinthodon, and not dissimilar from those of Sieboldia and Menobranchus. 
Near the skull, the scales of the throat remain in their natural position, and are seen to be densely imbricated, and arranged in curved rows, diverging from the mesial line. The scales of the abdomen are of larger size, and are scattered over the stone. Those of the throat are of a narrow ovate form, those of the abdomen wider, and some of them tending to rhomboidal in outline.

Twenty-four vertebra, in all, are scen in the specimen. Of these thirteen occur in continuous series, and appear to be lumbar. They are of small size, relatively to the dimensions of the head and limbs, and indicate a weak and flexible back. Other vertebræ, not in regular series, are dorsal, and have strong transverse processes with oblique articulating surfaces. A few are perhaps cervical and caudal. The bodies of the vertebræ have continuous bony walls, but thinner than in spécimens of larger size.

One half of the pelvis is well preserved, and shows a broad ilium, and strong ischiac and pubic bones. There are also broad scapular, and probably sternal bones, but crushed and imperfect. Few of the ribs remain, and these apparently only the smaller ones, as compared with other skeletons of which I have portions.

Several of the bones of the limbs remain in sufficiently good preservation to allow of measurement of their size. I am thus enabled to give the following dimensions of parts of the animal.

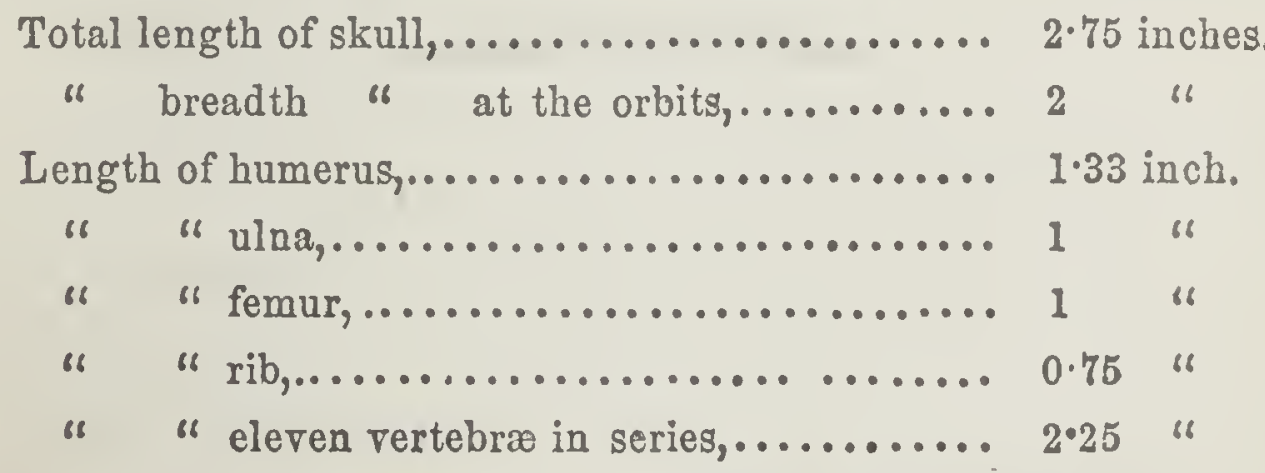

It would seem from these dimensions that the head was broad, and the trunk slender; the anterior limb, including the foot, half as long again as the head, and the posterior limb rather smaller or shorter than the anterior. It would thus appear that while the general form of the body was not unlike that of Menobranchus, the limbs were much larger, and must have carried the 
trunk without allowing any part of it to touch the ground, as would also seem to have been the case from the footprints found in the coal-formation beds, and the size and form of the toes of which make it likely that they belonged to this animal.

The limb-bones, though thin-walled and often crushed, evidently had broad articulating surfaces; and in the case of the forelimbs particularly, were large and strong in proportion to the dimensions of the head and vertebral column.

The large size of the fore-limb I suppose to have been related to a habit of walking or standing in shallow water, with the snout in the air, in the manner of newts, and the more rapid movements of the creature were probably performed by the tail. It is interesting to observe that in Hylonomus the proportions of the limbs were reversed-the hind limbs being much larger than the fore limbs.

From the relative dimensions of the bones, as compared with those of other specimens in my possession, I presume that this individual was three-fourths grown, and I doubt if its total length much exceeded one foot.

\section{EXPLANATION OF PLATE III.}

\section{Dendrerpeton Acadianum.}

Fig. 1.-Skull seen from below.

"2.-Inner tooth, magnified; from the jaw, Fig. 17.

"3.-Tooth of intermaxillary, magnified; from the bone in Fig. 13.

"4.-Series of inner teeth, less magnified.

"5.-Series of outer teeth of maxillary bone, Fig. 15, magnified.

"6, 7.-Sections of inner teeth.

" 8.-Portion of bone of skull, outer surface, twice the natural size.

"9.-Super-temporal bone, twice the natural size.

"10.-Cross section of humerus; (a) natural size; (b) magnified; (c) portion more highly magnified, showing canals and bone cells.

- Perhaps increased by flattening. 
Fig. 11.-Bone cells, highly magnified (after Quekett).

" 12.-Vomer? with teeth; (a) tooth magnified.

"13.-Intermaxillary with teeth.

"14. - Section of tooth of intermaxillary; (b) magnified; (a) portion highly magnified.

"15.-Maxillary bone with teeth.

"16.-Mandible with teeth.

"17.-Fragment of skull, with (a) outer teeth of maxillary; (b) inner teeth.

"18.-Cross section of a scale, magnified.

"19.-Outlines of scales, natural size.

"20.-Scale, twice natural size.

" 21.- Vertebra.

"6 22.-Caudal vertebra.

"23.--Vertebra broken across, showing neural and central cavities; (a) natural size; (b) section of a portion magnified, showing canals and bone cells.

"24. - Fragments of ribs.

" 25. -Scapular bone.

"26.-Humerus, crushed at the proximal end, with fragment of tho radius.

"27.-Fragments of femur, tibia, and fibula.

" 28.-Remains of peIvis.

"29.-Bones of the foot.

" 30.-Group of bones of the foot, in situ.

All the above are of the natural size, unless otherwise stated. 


\section{Dendrerpeton Oweni.}

Plate IV.

Among the reptilian remains found in erect trees at the South Joggins, there have occurred several portions of skeletons, which from their sculptured cranial bones, plicated teeth, and the forms of their scales and limb-bones, I have referred to the genus Dendrerpeton, but to individuals of much smaller size than the fullgrown specimens of $D$. Acadianum. It did not occur to me to suppose that these were specifically distinct from the larger individuals, until I observed that bones of this kind, contained in the collections sent by me to the Geological Society, or represented. in the figures drawn to illustrate one of my papers, were referred by Professor Owen, in his notes on these specimens and figures, in the Journal of the Geological Society, to the genus Hylonomus ; which is quite distinct from Dendrerpeton, as will be explained in the sequel.

I was thus induced to re-examine all the specimens in my collection, and the result has been to establish a strong probability that there is in reality a second species of Dendrerpeton, smaller than $D$. Acadianum, and differing from it in several points. This species I propose to name $D$. Oweni. It differs from $D$. Acadianum in the following particulars:-(1) Its much smaller size: (2) Its long and hooked teeth; Pl. IV, Figs. 2 to 8 ; (it will be seen that these teeth differ very markedly in their proportions and form from those of the larger species represented in Pl. III): (3) The greater plication of the ivory in the intermaxillary teeth; Figs. 8,9 ; (in $D$. Acadianum these teeth are, on the outside, simple almost to the base, and plicated on the inner side, while in this species they are plicated all around like the inner maxillary teeth): (4) The form of the skull, which has the orbits larger in proportion, and is also shorter and broader. On the other hand, when we have described the species of Hylonomus, it will be seen that this animal, except in size, differs from them quite as widely as does $D$. Acadianum. 
The distinctness of $D$. Oweni is further confirmed by the fact that I possess small jaw bones of Dendrerpeton, about the size of those of this species, but having the teeth similar in form to those of the larger species; these I suppose to have belonged to young individuals.

On examining the figures, it will be seen that the bones of the skull were corrugated as in the large Dendrerpeton, but with a smaller pattern. The forms of the jaw-bones also, and of the vertebræ, ribs, scapular bone, bones of the limbs, and bony scales, are very similar, and indicate that in general form this creature was not far removed from its larger relative. The bones of the foot, represented in Fig. 14, especially deserve attention. This is the most perfect foot of Dendrerpeton hitherto found; and I have enlarged it in the figure, in order more distinctly to show its parts. It presents three long toes, with traces of a smaller one at each side, so that there were probably five in all. If these toes be compared with the footprints on the slab discovered by Dr. Harding, represented in Pl. I, Fig. 2, it will be seen that they very closely correspond, though the toes of the present species are much smaller. The footprints are precisely those which we may suppose an animal of the size of Dendrerpeton Acadianum would have made, if, as the bones found render in every way probable, this larger species had a foot similar to that of $D$. Oweni. I suppose, for this reason, that these footprints are really those of $D_{\text {en- }}$ drerpeton Acadianum; and that this species continued to exist from the time of the lower coal measures, to the period when those higher beds of the series, in which its bones are found at the Joggins, were deposited.

The present species must have lived in the same places with its larger relative; but may have differed somewhat in its habits. Its longer and sharper teeth may have been better suited for devouring worms, larvæ or soft-skinned fishes, while those of the larger Dendrerpeton were better adapted to deal with the mailed ganoids of the period, or with those smaller reptiles which were more or less protected with bony or horny scales. 


\section{Remains of Skin and Horny Scales.}

Plate I, Fig. 5; Plate IV, Figs. 22 to 34, and Plate V, Figs. 22 to 29.

In one of my earliest explorations of the reptile-bearing stumps of the Joggins, I observed on some of the surfaces, patches of a shining black substance, which on minute examination proved to be the remains of cuticle, with horny scales and other appendages. The fragments were preserved; but I found it impossible to determine with certainty to which of the species whose bones occur with them they belonged, or even to ascertain the precise relations of the several fragments to each other. I therefore merely mentioned them in general terms, and stated my belief that they may have belonged to the species of Hylonomus.* More recently other specimens have been obtained, and I have undertaken the detailed examination of the whole. I shall now endeavour to describe the principal or most continuous fragments, and afterward to consider the probabilities of their having belonged to certain of the reptiles entombed with them. I do this here, rather than under the titles of these several animals, on account of the uncertainty which still rests on the assignment of certain portions of this cuticle to the species in question, and which renders it more convenient to consider these peculiar remains in one place, and to compare the different portions with each other.

(1) One of my specimens is a flattened portion of cuticle $2 \frac{1}{4}$ inches in length. The greater part of the surface is smooth and shining to the naked eye, and under the microscope shows only a minute granulation. A limited portion of the upper, and I suppose, anterior part is covered with imbricated scales, which must have been membranous or horny, and generally have a small spot or pore near the outer margin, some having in addition smaller scales or points on their surfaces, (Pl. IV, Figs. 22 and 25). In contact with the upper part of this specimen there were many fragments of the skull of Dendrerpeton Oweni. 
(2) Another portion of cuticle, similarly marked, appears to preserve the form of the posterior part of the body and tail of the animal, and also a mark representing the point of attachment of the hind leg; near to which, and along the dorsal ridge, is a portion of the skin covered with much smaller scales. It is represented in Pl. I, fig. 5. This was found in close proximity to a mass of bones of Dendrerpeton Oweni, mingled with some of $H y$ lonomus Lyelli.

(3) A third and still larger surface of integument with similar markings, has upon it a number of vertebre and detached bones of the small reptile Hylonomus Wymani, to be described in the sequel; for which species however it would be mucb too large a covering.

(4) Another well preserved fragment, less than two inches in length, exhibits very different markings. It is nearly covered with very small imbricated scales, thicker than those on the specimens previously described. On either side of what seems to have been the middle line of the back, there is a series of pointed flat horny processes, which probably formed a double spinous crest. Without these there are tufts of strong bristles, and exteriorly to these last are rows of flat, thick, horny plates, transversely wrinkled. Near to these was a row of conical truncated tubercles. Sections of these appendages show them to have been horny and attached to the cuticle. None of them have bony structure. Figs. 23, 26, 27, 28, 29, 30, PI. IV, represent this portion of cuticle, with magnified views of its markings, and of the structure of one of the thicker scaies. Fig. 26 shows a portion of the ordinary scaly skin magnified and viewed by transmitted light. Fig. 27 exhibits a few of the bristle-like appendages from the point marked $a$ in fig. 23 . Fig. 28 shows four of the bluntly-conical points seen in a portion of skin a little beyond the margin of the fragment in fig. 23, but evidently belonging to it. Fig. 24 is an enlarged representation of one of the flat horny scales from the point $b$ in fig. 23 ; and fig. 29 is a magnified section of a portion of the same scale, showing a compact translucent brown 
substance with round canals, and near the margin, a portion much more abundantly supplied with these apparently vascular canals, while without this part there is a thin layer of more dense material. Fig. 30 shows a portion of the surface of fig. 23, more highly magnified, and displaying at $a$ ordinary scales, at $b$ horny pointed organs; at $c$ bristly appendages, and at $d$ large plates. The whole of these parts, though displaced by the flattening and wrinkling of the skin, are in good preservation, and show their characters in great perfection under the microscope. They are all black and shining as if carved in jet.

(5) Near this last portion of cuticle, and possibly belonging to it, are pointed and probably membranous appendages, marked on each side with rows of scales not overlapping, and each with a pore in its centre. The manner in which these appendages are bent and wrinkled, shows that they.must have been soft, except at the tips, which seem to have been hard and horny, and they are arranged in series, as if originally placed along the sides of the neck or abdomen, or both. These appendages are represented in Pl. IV, figs. 31 and 32. A magnified representation of the point of one of them is given in fig. 33 , and a small portion, still more highly magnified, in fig. 34. The use of these appendages it is not easy to conjecture. They remind us of the gular pouches of iguana, and of the lateral expansions of some geckos and of the Draco volans. Possibly they formed lateral parachutes, aiding the animal in moving over soft mud, or perhaps in leaping or swimming.

(6) Some other fragments appear to have belonged to a different species from either of the foregoing, and are represented in Pl. V. The best preserved specimen (Fig. 22), which is about one inch in length and half an inch in breadth, is covered with very small imbricated scales. It is crossed by six or seven obscure ridges, which both at the bottom and along a mesial line, projected into points covered with larger scales. A row of large scales with round pores, connects these along the lower side (Figs. 23 and 24.) If, as seems probable, this fragment belonged to the 
side of the trunk or tail, it would perhaps indicate a division of the sub-cutaneous muscles into an upper and lower band, as in the newts. A separate fragment, with transverse horny ridges (Figs. 26 and 27 ), and another with a longer lobe similar in structure to those above mentioned (Figs. 28 and 29), may perhaps be referred to the same animal. A larger patch of skin presents similar imbricated scales, but without a mesial line, and with an edging of larger scales (Fig. 25).

Six species of reptiles have left their bones in the repositories containing these remnants of cuticle. Of these, Dendrerpeton Acadianum was an animal of too great size to have been clothed with integument of this character and of such dimensions. Hylonomus aciedentatus, described in Section VIII, and Hylerpeton Dawosoni, Section $\mathrm{X}$, are each represented by only a single specimen, and these did not occur in proximity to any of the portions of cuticle, except that the appendages in Pl. IV, fig. 32, were found near a specimen of the former. Of the three remaining species, Dendrerpeton Oweni, from its size, the number of specimens found, and the juxtaposition of their bones to the fragments of cuticle, appears to have the best claim to the integument included under Nos. 1, 2, and 3; and in this case, while the creature had its throat, and perhaps its abdomen, armed with bony scales, its upper parts and tail, as well as its limbs, had a uniform covering of small thin imbricated horny scales, in the manner of many modern reptiles.

If the remaining portions of integument, Nos. 4 and 5 , as would seem likely, belonged to two species, both of smaller dimensions, there would seem little reason to doubt that these were Hylonomus Lyelli (Section VII) and $H$. Wymani (Section IX). In this case, both of these species must have possessed a highly ornate covering of horny scales and appendages, comparable with that of any of the modern lizards, while there seems good reason to believe, as stated in a previous paper, that they were in part protected by bony scales somewhat like those of Dendrerpeton. These points, however, we shall consider more in detail under the sections which refer to the species of Hylonomus. 
Before leaving these curious specimens of ancient skin, the most ancient I suppose known to exist, it is of interest to observe that the thicker portions, when broken across, have the aspect of jet, or of pure shining coal, and that thin slices, under the microscope, have the same rich brown colour with that material, though rather more translucent. When burned, fragments of the substance give a strong flame, and a bituminous and ammoniacal odour. We have thus an example of the production of coal from animal membrane, no doubt gelatinous and horny in the first instance, but which has proved itself capable of the same chemical changes that have been experienced by the vegetable matter buried with it. In order that this substance should he preserved in this way, it would be necessary that it should either be kept dry and hard, or that it should be immediately buried in matter impervious to air, and kept moist. The latter conditions are the more probable. The preservative qualities of the peaty vegetable matter imbedded with it must also be considered; and it is possible that these hollow stumps partly filled with fragments of Sigillaria bark, may have formed natural tan-pits, in which animal membranes would be preserved in a manner impossible in ordinary sediments. If this were the case, we may yet find an entire reptile, preserved as a flattened mummy, in one of these strange repositories.

\section{Explanation of Plate IV.}

\section{Dendrerpeton Oweni, and Dermal Appendages.}

Fig. 1.-Skull.

"2.-Portion of mandible.

"3.-Maxillary bone, with outer teeth.

"4.-Teeth of same enlarged.

"5.-Maxillary bone, with inner teeth.

"6. Tooth of same enlarged.

"7.-Intermaxillary.

" 8.-Tooth of same enlarged.

" 9.-Section of same enlarged. 
Fig. 10 and 11.-Vertebræ.

" 12.-Portion of pelvis.

"13.-Fragments of ribs.

"14.-Bones of foot enlarged, (a) natural size.

" 15.-Scapular bone.

"16.-Humerus.

"17.-Bones of hind leg.

" 18 and 19.-Sculpturing of cranial bones, enlarged.

"20.-Bony scale.

"21.-Socket of inner tooth enlarged.

" 22 and 25.-Integument of Dendrerpeton Oweni, with imbricated scales.

"23.-Integument of Hylonomus Lyelli.

"24,26,27,28,30.-Scales and appendages of the same enlarged.

"29,-Section of scale represented in Fig. 24.

"31.-Angular pendants or processes of $H$. Lyelli.

" 32.-The same of $H$. aciedentatus.

" 33 and 34.-Portions of the same enlarged. 


\section{HyLonomus Lyelit.}

Plate V.

In the original reptiliferous tree, discovered by Sir C. Lyell and the writer, at the Joggins, in 1851, there were, beside the bones of $D$ en drerpeton Acadianum, some small elongated vertebræ, evidently of a different species. These were first detected by Prof. Wyman, in his examination of these specimens, and were figured, but not named, in the notice of the specimens in the Journal of the Geological Society, Vol. IX. In a subsequent visit to the Joggins, I obtained from another erect stump many additional remains of these smaller reptiles, and, on careful comparison of the specimens, was induced to refer them to three species, all apparently generically allied. I proposed for them the generic name Hylonomus, "forest-dweller." They were described in the proceedings of the Geological Society for 1859, with illustrations of the teeth and other characteristic parts.* The smaller species first described I named H. Wymani; the next in size, that to which this article refers, and which was represented by a larger number of specimens, I adopted as the type of the genus, and dedicated to Sir Charles Lyell. The third and largest, represented only by a few fragments of a single skeleton, was named $H$. aciedentatus.

Hylonomus Lyelli was an animal of small size. Its skull is about an inch in length, and its whole body, even if, as was likely, furnished with a tail, could not have been more than six or seven inches long. No complete example of its skull has been found. The bones appear to have been thin and easily separable; and even when they remain together, are so much crushed as to render the shape of the skull not easily discernible. They are smooth on the outer surface to the naked eye; and under a lens show only delicate uneven strix and minute dots. They are more dense and hard than those of Dendrerpeton, and the bone-cells are more elongated in form. The bones of the snout would seem to have been 
somewhat elongated and narrow. A specimen in my possession shows the parietal and occipital bones, or the greater part of them, united and retaining their form. We learn from them that the brain-case was rounded, and that there was a parietal foramen. There would seem also to have been two occipital condyles; (see plate V, fig. 8.). Several well preserved specimens of the maxillary and mandibular bones have been obtained. They are smooth, or nearly so, like those of the skull, and are furnished with numerous sharp, conical, teeth, anehylosed to the jaw, in a partial groove formed by the outer ridge of the bone. In the anterior part of the lower jaw there is a group of teeth larger than the others. The intermaxillary bone has not been observed. (Figs. 1, 2, 3, 4, 5,6.) The total number of teeth in each ramus of the lower jaw was about forty, and the number in each maxillary bone about thirty. The teeth are perfectly simple, hollow within, and with very fine radiating tabes of ivory. (Fig. 7, $a$ and b.) The vertebræ have the bodies cylindrical or hour-glass shaped, covered with a thin, hard, bony plate, and having within a cavity of the form of two cones, attached by the apices: This cavity was completely surrounded by bone, as it is filled with stained calc-spar in the same manner as the cavities of the limb bones. It was probably occupied by cartilage. The vertebræ were apparently bi-concave. The neural spines are short and broad, with zygapophyses, and are not separable from the bodies, the neural arches being perfectly anchylosed to the bodies of the vertebræ. There are, on the dorsal vertebræ, strong diapophyses or lateral spines, to which the ribs were articulated. (Figs. 15, 16, 17.) The ribs are long, curved, and at the proximal end have a shoulder and neck. (Figs. 1, 10, 18.) They are hollow, with thin hard bony walls. The anterior limb, judging from the fragments procured, seems to have been slender, with long toes, four or possibly five in number. A humerus is seen in fig. 1, and bones of the toes magnified in fig. 11 . The posterior limb was longer and stronger, and attached to a pelvis so large and broad as to give the impression that the creature enlarged considerably in size toward 
the posterior extremity of the body, and that it may have been in the habit of sitting erect. The thigh bone is well formed, with a distinct head and trochanter, and the lower extremity flattened and moulded into two articulating surfaces for the tibia and fibula, the fragments of which show that they were much shorter. The toes of the hind feet have been seen only in detached joints. They seem to have been thicker than those of the fore foot. Detached vertebræ, which seem to be caudal, have been found, but the length of the tail is unknown. The limb bones are usually somewhat crusbed and flattened, especially at their articular extremities, and this seems to bave led to the error of supposing that this flattened form was their normal condition; there can be no doubt, however, that it is merely an effect of pressure. The limb bones present in cross section a wall of dense bone with elongated bonecells, surrounding a cavity now filled with brown calc-spar, and originally occupied with cartilage or marrow. (Figs. 12, 13, 14.) Nothing is more remarkable in the skeleton of this creature than the contrast between the perfect and beautiful forms of its bones, and their imperfectly ossified condition, a circumstance which raises the question whether these specimens may not represent the young of some reptile of larger size.

The dermal covering of this animal is represented in part by oval bony scales, which are so constantly associated with its bones that I can have no doubt that they belonged to it, being, perhaps, the clothing of its lower or abdominal parts; while above, it was probably clad in the beautiful scaly covering described in the last section. The bony scales are represented magnified in Plate $\mathrm{V}$. figs. 19. 20, and 21. It will be seen that they differ in form from those of Dendrerpeton; they are also much thicker. On the inner side they are concave, with a curved ledge or thickened border at one edge. On the outer side they present concentric lines of growth.

The only specimens which afford much information as to the general form of Hylonomus Lyelli are those represented in Plate $\mathrm{V}$, figs, 1 and .9. The first is the original specimen, from which I described the species in the paper already referred to. The 
bones, being small and of dark colour, are not very conspicuous; and many of them are broken, but many are beantifully perfect; and even those which are removed have left very distinct moulds of their form in the fine-grained matrix. In the figure $I$ have carefully traced their outlines in their natural position, with the exception of the maxillary bone and mandible, which are removed from their place in the matrix, to bring the whole into a more compact form. The specimen also shows, in addition to the bones delineated, many fragments of the skull and scapular bones, crushed in such a manner that their forms cannot be distinguished. The specimen shows remains of thirty vertebræ, of which four appear to belong to the neck, and the rest are probably nearly all dorsal and lumbar. Three of the most perfect are represented enlarged, in figs. 15 and 16. Of about twenty ribs, more or less complete fragments remain. The fore limb is represented only by the impression of a humerus, (e), but other bones which may have belonged to it are scattered elsewhere on the stone. The pelvis, $(i)$ is nearly entire, though crushed and flattened. One thigh bone remains tolerably perfect, and beside it lie the tibia and a part of the fibula, with several bones of the foot. The dimensions of these parts are as follows:-

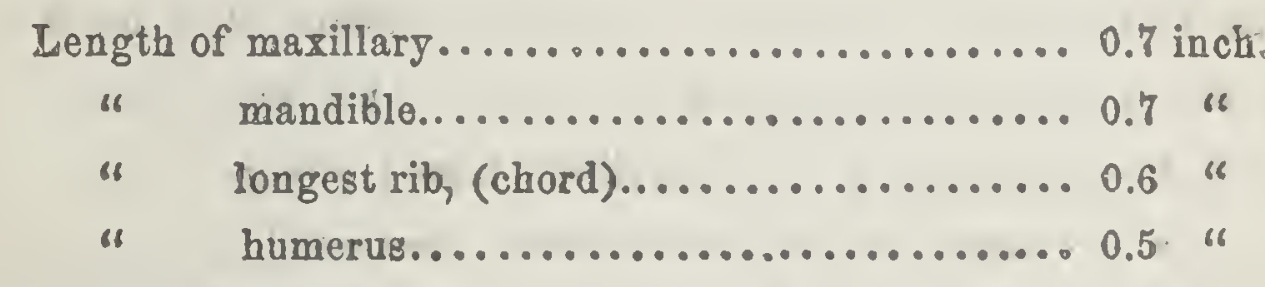

Length of femur..................... 0.7 inch.

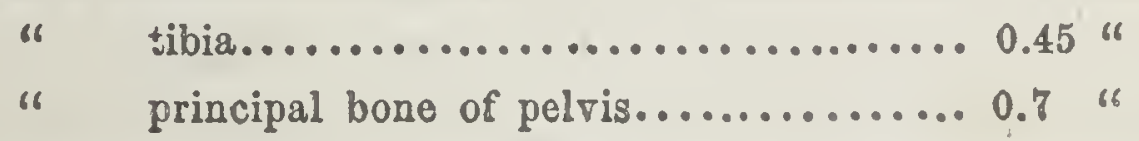

The other specimen above referred to, (Fig. 9.) shows the bones of the trunk, and part of those of the hind and fore limb of a small individual, nearly in their natural position. This specimen I have very recently obtained; in breaking open a mass of matrix in which I did not suspect its existence. It shows the humerus and radius and ulna in a tolerable state of preservation, with a fragment of the scapula. About thirteen dorsal and lumbar vertebræ can be 
made out, nearly in their natural position ; and there are remains of five of the ribs. The hind limb is represented by fragments of the femur, tibia, and fibula. I believe that the maxillary represented in fig. 3, though now in a detached piece of stone, belonged to this skeleton.

While referring to these, my most perfect specimens, I think it proper to quote my original description of the species, based on the first of them, and published in 1859; as the subject has since been unfortunately obscured by inaccurate descriptions, consequent on the mixture of specimens and drawings, sent by me to London for further examination. I quote from the journal of the Geological Society, Vol. XVI.

\section{"Hylonomus, gen. nov."}

"The other reptilian remains represent three species belonging to a generic form, which, so far as I am aware, has not been previously observed, and for which, in allusion to its forest habitat, I propose the above name. As its typical species I shall describe that which I would name Hylonomus Lyelli. Its cranial bones are thin and smooth; the condyle I have not been able to observe, but there is a parietal foramen, and the parietal bones are arched in such a manner as to indicate a rounded rather than flattened skull, and a somewhat capacious brain-case. Its teeth are numerous (about twenty-six in each maxillary bone), elongated, conical, closely set in a single series, in a furrow, protected externally by an elevated alveolar ridge. In the intermaxillaries and extremities of the mandibles the teeth are larger than elsewhere. Fig. 14, (Fig. 5, Plate V. of this paper) represents a portion of the teeth of the maxillary bone as exposed by the fracture of the outer ridge. The vertebræ are imperfectly preserved, but appear to have been ossified, bi-concave, and with well-developed spinous processes. The ribs are long and curved; and there are traces of numerous accessory pieces which have been attached to their extremities. The pelvis is of large size and remarkable form; the ilium long and expanded below; the ischium greatly expanded; the pubis ex- 
panded and triangular where it joins the ischium, and round and arched toward the symphysis. The femur is thick and nearly straight, the tibia short and stout, the fibula slender, the phalanges broad. The hind limb thus largely developed must have been capable of supporting the whole weight of the body in standing or leaping. The anterior extremities appear to have been comparatively slender, with thin and long fingers. A few scattered vertebræ lying posteriorly to the pelvis, may perhaps be remains of a tail. There was a dermal covering of small ovate bony scales, of which, however, only a few scattered specimens remain. This species is evidently quite remote from the ganocephalous and labyrinthodont types of batrachians, and in many respects approaches to lacertians. It may perhaps be allied to the Telerpeton of Elgin, but does mot appear to resemble any reptile hitherto found in the coal-formation."

It is evident, from the remains thus described, that we have in Hylonomus Lyelli an animal of lacertian form, with large and stout hind limbs, and somewhat smaller fore limbs, capable of walking and running on land; and though its vertebræ were imperfectly ossified externally, yet the outer walls were sufficiently strong, and their articulation sufficiently firm, to have enabled the creature to erect itself on its hind limbs, or to leap. They were certainly proportionally larger and much more firmly knit than those of $D e n$ drerpeton. Further, the ribs were long and much curved, and imply a respiration of a higher character than that of modern batrachians, and consequently a more highly vitalized muscular system. If to these structural points we add the somewhat rounded skull, indicating a large brain, we have before us a creature which, however puzzling in its affinities when anatomically considered, is clearly not to be ranked as low in the scale of creation as modern tailed batrachians, or even as the frogs and toads. We must add to these also, as important points of difference, the bony scales with which it was armed below, and the ornate apparatus of horny appendages, with which it was clad above. These last, as described in the last section, and illustrated in Plate IV., shew that this little 
animal was not a squalid, slimy dweller in mud, like Menobranchus and its allies, but rather a beautiful and sprightly tenant of the coal-formation thickets, vying in brilliancy, and perhaps in colour$n g$, with the insects which it pursued and devoured. Remains of as many as eight or ten individuals have been obtained from three erect sigillarix, indicating that these creatures were quite abundant, as well as active and terrestrial in their mode of life.

With respect to the affinities of this species, I think it is abundantly manifest that it presents no close relationship with any reptile hitherto discovered in the Carboniferous system. The only indications of which I am aware of animals of this age, likely to be of similar type, are certain vertebræ discovered by Mr. Wheatley and Dr Newberry, in the coal formation of Ohio; and described; but not named, by Prof. Wyman, in Silliman's Journal, Vol. XXV, in connection with the singular bratrachian named by him Raniceps Lyelli; which, in its broad frog-like head and want of ribs, differs materially from the creature now under examination. It is scarcely necessary to say that the characters above described, and illustrated by the figures in Plate $\mathrm{V}$, entirely remove this animal from Archegosaurus and Labyrinthodon; as well as from all the other creatures associated with them in the orders Ganocephata and Labyrinthodentia of Owen. Equal difficulties attend the attempt to place it in any other group of recent or extinct batrachians or proper reptiles. The structures of the skull, and of some points in the vertebræ, certainly resemble those of batrachians; but on the other hand, the well-developed ribs, evidently adapted to enlarge the cliest in respiration, the broad pelvis, and the cutaneous covering, are unexampled in modern batrachians, and assimilate the creature to the true lizards. I have already, in my original description above quoted, expressed my belief that Hylonomus may have had lacertian affinities, but I do not desire to speak positively in this matter; and shall content myself with stating the following alternatives as to the probable relations of these animals. (1)They may have been true reptiles of low type, and with batrachian tendencies:

(2) They may have been repre- 
sentatives of a new family of batrachians, exhibiting in some points lacertian affinities.

(3) They may have been the young of some larger reptile, too large and vigorous to be entrapped in the pit-falls presented by the hollow Sigillaria stumps, and in its adult state losing the batrachian peculiarities apparent in the young. Whichever of these views we may adopt, the fact remains, that in the structure of this curious little creature we have peculiarities both batrachian and lacertian, in so far as our experience of modern animals is concerned. It would however accord with observed facts in relation to other groups of extinct animals, that the primitive batrachians of the coal period should embrace in their structures, points in after times restricted to the true reptiles. On the other hand, it would equally accord with such facts that the firstborn of lacertians should lean toward a lower type, by which they may have been preceded. My present impression is, that they may constitute a separate family or order, to which I would give the name of Microsauria, and which may be regarded as allied, on the one hand, to certain of the humbler lizards, as the Gecko or Agama, and, on the other, to the tailed batrachians.

It is likely that Hylonomus Lyelli was less aquatic in its habits than Dendrerpeton: Its food consisted, apparently, of insects and similar creatures. The toeth would indicate this, and near its bones there are portions of coprolite, containing remains of insects and myriapods. It probably occasionally fell a prey to Dendrerpeton, as bones, which may have belonged either to young individuals of this species or to its smaller congener $\boldsymbol{H}$. Wymani, are found in larger coprolites, which may be referred with probability to Dendrerpeton Acadianum. 


\section{Explanation of Plate V. \\ Hylonomus Lyelli, and Dermal appendages.}

Fig. 1.-Remains of a skeleton of a large individual of Hylonomus Lyelli;

(a) Maxillary; (b) Nandible; (c) Ribs; (d) Vertebræ;

(e) Humerus; $(f)$ Femur; $(g)$ Tibia; (h) Fibula, (i)

Pelvis; (k) Foot.

"2.-Right Mandible.

"3.-Maxillary.

"4,5.-Portions of Maxillary, magnified.

"6.-Extremity of Mandible, magnified.

"7.-Sections of teeth; (a) magnified, (b) highly magnified.

" 8.-Portion of cranium, magnified; $(a)$ natural size, $(b)$ transverse section.

" 9.-Skeleton of the trunk of a small individual of $H$. Lyelli; (a) Fore limb, (b) Hind limb, (c) Ribs.

"10.-Ribs from the slab, Fig. 1, magnified.

"11.-Fore foot, magnified; (a) natural size.

" 12.-Cross section of flattened femur, magnified.

" 13, 14.-Portions of the bone of the same, more highly magnified.

" 15.-Pair of Vertebræ (dorsal), magnified.

" 16.- Vertebra magnifled.

" 17.- Vertebra broken across and magnified, showing (a) neural arch, (b) diapophysis, and (c) central cavity.

‘ 18. - Head of a rib, magnified.

"19,20,21.-Bony scales, magnified, (a) natural size.

"22.-Portion of cuticle, probably of Hylonomus Wymani.

" 23,24 .-Parts of the same magnified.

", 25.-Lower margin of another portion of cuticle, magnified.

" 26, 27.-Ridged horny scale, natural size and magnified.

" 28, 29.-Cutaneous lobe, natural size and magnified. 


\section{VIII.-Hylonomus Aciedentatus.}

Plate VI, Figs. 1 to 16.

This species is founded on a single imperfect specimen obtained by me at the Joggins in 1859 , and described in the Journal of the Geological Society, Vol. XVI. In this description, I mentioned, as probably belonging to this species, certain detached bones which I have since found reason to attribute to Dendrerpeton Oweni. These did not however materially interfere with the characters of species, which I shall give here from the fragments represented in Plate VI, Figs. 1 to 16 , and which occur together in the matrix in such a manner as to render it certain that they belonged to the same individual.

In size, $H$. aciedentatus was about twice as large as the species last described. Its teeth are very different in form. Those on the maxillary and lower jaw are stout and short, placed in a close and even series on the inner side of a ridge or plate of bone. Viewed from the side they are of a spatulate form, and pre. sent a somewhat broad edge at top as in Fig. 4. Viewed in the opposite direction, they are seen to be very thick in a direction transverse to that of the jaw, and are wedge-shaped as in Fig. 5. There are about forty on each side of the mandible, and about thirty on each maxillary, as seen in Figs. 1, 2, and 3, of which the two first are magnified slightly, the last natural size.*

Since the publication of my previous paper, I have ascertained that the intermaxillary bones bore teeth of the form represented in Fig. 6. They are larger than the others, thick and coming to a blunt point, which is seamed with longitudinal and stightly spiral ridges. This singular tooth must have been a most efficient instrument for crushing and penetrating the coats of crustaceans and insects, or the bony armour of the smaller ganoid fishes. Remains exist at the extremity of the lower jaw, which show that

* In Prof. Owen's paper, J.G.S., Vol. 18, this bone is figured, but incorrectly stated to be twice natural size, and referred to $H$. Lyelli. 
a few teeth there also were larger than the others, but whether they differed in form cannot be determined. The pulp cavity of the teeth is less extensive in proportion than in H. Lyelli, and the structure in the cross section is simple, showing merely radiating ivory tubes, as in Fig. 7. The bone represented in Fig. 8, was found with these remains, and as it is too large for the last species, and different from anything known in Dendrerpeton, it probably belongs to the creature now under consideration. It is thin and smooth, except at the upper margin, where it has in the centre a group of small conical teeth. It evidently belongs to the palate, and somewhat resembles the palatal bone of Menobranchus, but is broader, and the latter has no teeth. Detached fragments of the skull show that its bones were thin and dense and smooth on the surface as in H. Lyelli. That represented in Fig. 9 would seem to be a frontal bone seen from the inside.

The remains of $H$. aciedentatus are too scanty to warrant much certain inference as to its form. Its vertebræ would seem to have resembled those of $H$. Lyelli, but to have been elongated and more thoroughly ossified (Fig. 16). Its ribs are similar in form and proportion to those of the last named species (Figs. 10 and 11). A pelvic bone and some detached phalangial bones (Figs. 12 and 13) as well as very fragmentary limb bones, would indicate that its limbs were well developed. Its external scales are similar to those of the last species but larger, and a few fragments of skin show scales and appendages similar to those of $H$. Lyelli, but of greater dimensions (Figs. 15 and 62). The microscopic structure of its bone is also similar to that in the last species (Fig. 17). No doubt a more perfect specimen would show many points of difference between these species, not now appreciable; but in the mean time the very different form of the teeth is a sufficient distinction. In $H$. Lyelli these are conical and pointed. In the present species they are of a peculiar wedge shape-their diameter transversely to the jaw being the greatest at the base, while at the top they are sharpened to an edge. The peculiar form of the intermaxillary teeth may also serve as a distinctive 
character, though those of $H$. Lyelli are not yet known. The form of the vertebrix would further seem to, indicate different proportions of body. On the whole, while this species is in all probability generically related to the last, it is certainly specifically distinct. Its habits and food may have been similar, but its dental apparatus was stronger and more formidable.

EXPLANATION OF PLATE VI, FIGS. 1 TO 16, AND FIG. 62. Hylonomus aciedentatus.

Fig. 1-Maxillary bone, magnified, (a) natural size.

"2-Mandible magnified, (a) natural size.

"3-Portion of mandible, natural size.

" 4 and 5-Tooth, seen from the side and front.

"6-Tooth of intermaxillary.

"7-Cross section of tooth, magnified.

" 8-Palatal bone with teeth.

"9-Frontal bone.

" 10 and 11-Rib natural size and cross section enlarged.

" 12-Pelvic bone.

"13-Phalangial bone.

" 14 and 15-Bony scales magnified.

"16-Broken vertebra.

" 62-Portion of skin with horny scales. 


\section{IX.-Hylonomus Wymani.}

Plate VI, Figs. 18 to 31.

This is the species of Hylonomus originally detected by Prof. Wyman in the specimens brought from the Joggins by Sir C. Lyell and myself. Remains of several additional individuals have since been found, but no skeleton approaching to completeness. I shall describe this the most diminutive of the reptiles of the Nova Scotia coal, with the aid of the fragments represented in Plate VI, Figs. 18 to 31, most of which are almost microscopic in size.

The skull seems to have been much of the same form as in $H y$ Conomus Lyelli, but very thin and delicate, so that all the specimens hitherto found are crushed and fragmentary. The maxillary and mandibular bones are furnished with teeth which are bluntly conical in form, and in the latter bone seem to be confined to its front part, or to be very small posteriorly. They are thus much fewer in number than in the species last named. I have been able to make out only 22 in the lower jaw $r$ and they are alternately large and small, as if replaced in this manner as worn out. Their structure is of the same simple character as in the other species of Hylonomus, and they have large pulp cavities.

The vertebræ of this species are singular and characteristic. The bodies are elongated and hour-glass shaped, with an internal carity of the same form filled with calc spar (Fig. 30), and probably once occupied by cartilage. They have, in the dorsal region at least, strong articulating and lateral processes, and were furnished with numerous delicate ribs (Figs. 24, 25, 27): In one of my specimens as many as 38 of these little vertebræ may be seen lying together, and many of them attached to each other. This would indicate that the body was long and slender. It was furnished with limbs, similar to those of $H$. Lyelli, but very small and slender. The pelvis is of the same expanded form with that of the last species, and a pair of fore feet lying together on one slab, show the remains of four slender toes (Fig. 29): The bones of the limbs are very delicate and thin walled (Fig. 26). The 
bony scales are oval, and similar to those of the other species of the genus, but very small (Fig. 31). I suppose it probable that the fragments of skin with imbricated scales represented in Plate V, Figs. 22, 23, and 24, may have belonged to this species, but I cannot certainly affirm that this was the case.

In length, Hylonomus Wymani could not have exceeded four or five inches, and its form was thin and slender. It may be questioned whether this little creature was not the young of one of the other species. The form of the vertebræ and teeth would, I think, prevent us from supposing that it stood in this relation to H. Lyelli. To H. aciedentatus it bears a stronger resemblance in these respects, though not sufficient to render specific identity probable; and the occurrence of so many specimens of the smaller species, without any of intermediate size, renders it likely that it did not attain to any greater dimensions.

Hylonomus Wymani probably fed on insects and larvæ, and searched for these among the vegetable debris of the coal swamps, which would afford to a little creature like this abundant shelter. It occasionally fell a prey to its larger reptilian contemporaries; for quantities of its tiny bones occur in coprolitic masses probably attributable to Dendrerpeton. It is interesting to find reptilian life represented at this early period, not only by large and formidable species, but by diminutive forms, comparable with the smallest lizards and newts of the modern world. The fact is parallel with that of the occurrence of several small mammalian species in the mesozoic beds. It will be still more significant in this respect if the species of Hylonomus should be found to be truly lacertian rather than batrachian. 
EXPLANATION OF PLATE VI, FIGS. 18 TO 31.

Hylonomus Wymani.

Fig. 18-Lower jaw with teeth, magnified.

" 19-Anterior part of lower jaw more magnified.

"20-Portion of maxillary bone with teeth, magnified.

" 21-Maxillary bone, natural size.

" 22-Lower jaw, natural size.

"23-Vertebræ, natural size.

" 24 and 25-Vertebræ, magnified.

"26-Humerus, natural size and magnified.

"27-Rib, natural size and magnified.

" 28-Pelvic bone, natural size and magnified.

"29-Foot; the line shows the natural size.

" 30 -Broken vertebra magnified, showing internal cavity.

"31-Bony scales, natural size and magnified. 


\section{X.-Hylerpeton Dawsoni.}

Plate VI, Figs. 32 to 46.

In the more or less laminated material which fills the interior of the erect trees of the Joggins, it often happens that the more distinctly separable surfaces are stained with ferruginous or coaly matter, or with fine clay, so that the fossils which occur on these surfaces, and which would otherwise be more available than those in more compact material, are rendered so obscure as readily to escape observation. This was unfortunately the case with one of the most interesting specimens contained in the last of these trees which I had an opportunity to examine. It consisted of the detached bones of a reptile scattered over a surface so blurred and stained that they escaped my notice until most of them were lost; and I was able to secure only a jaw bone and fragments of the skull, with a few of the other bones. On these fragments Prof. Owen founded the genus Hylerpeton and the species named at the head of this article. His description is as follows:

"This specimen consists of the left ramus of a lower jaw (Fig. 32), which has been dislocated from the crushed head, of which the fore end of the left premaxillary is preserved, terminating near the middle of the series of the teeth of the more advanced mandible. A fragment of the left maxillary, which has been separated from the premaxillary, overlaps the hinder mandibular teeth. The fore part of the mandible is wanting. The teeth in the remaining part are larger and fewer, in proportion to the jawbone, than in Hylonomus or Dendrerpeton. They have thicker and more obtusely terminated crowns; they are close-set where the series is complete at the fore part of the jaw, and their base appears to have been anchylosed to shallow depressions on the alveolar surface. The shape of what is preserved of the upper jaw affords the only evidence, and not very decisively, that the present fossil is not part of a fish. It inclines the balance, however, to the reptilian side; and, accepting such indication of the 
class-relations of the fossil, it must be referred to a genus of Reptilia distinct from those it is associated with in the Nova Scotian coal, and for which genus I would suggest the term Hylerpeton.

"A small part of the external surface of the dentary bone shows a longitudinally wrinkled and striate or fibrous character. The outer bony wall, broken away from the hinder half of the dentary, shows a large cavity, now occupied by a fine greyish matrix, with a smooth surface, the bony wall of which cavity has been thin and compact. We have here the mark of incomplete ossification, like that in the skeleton of Archegosaurus. The crushed fore part of the right dentary bone, with remains of a few teeth, is below the left dentary, and exemplifies a similar structure. The teeth slightly diminish, though more in breadth than length, towards the fore part of the series: here there are nine teeth in an alveolar extent of 10 millimeters, or nearly 5 lines. The base of the teeth is longitudinally fissured, but the fissures do not extend upon the exserted crown. In their general characters, the teeth manifest at least as close a resemblance to those of Ganocephala as of Lacertia or any higher group of Reptilia; whilst their mode of implantation, with the structure and sculpturing of the bone, weigh in favour of its relations to the lower and earlier order of the cold-blooded Vertebrates."

I can add to the above description only a few facts obtained from careful examination of other fragments imbedded in the matrix. One of these is a portion of a maxillary bone (Fig. 32). It has teeth similar to those of the lower jaw in form (Figs. 34 and 35), but the last but one is twice the size of the other's, and seems to have been implanted in a deep socket. All of the teeth have large pulp cavities, and the inner surface of the ivory is marked with slight furrows which are represented by ridges on the outer surface of the stony matter filling the pulp cavities (Fig. 36). The ivory of the teeth, however, which is very much coarser than that of the species of Hylonomus, presents in the cross section a simple structure of radiating tubes (Fig.37). The surface of the cranial bones, of which some fragments remain, is 
marked in the same striate manner alluded to above by Prof. Owen (Figs. 42,43). The microscopic structure of the bone is muci coarser than that of Hylonomus or Dendrerpeton, the cells being larger and in some portions less elongated (Fig. 46). That the creature had stout ribs is shown by the fragments represented in Fig. 40 ; but the vertebræ are represented only by a few bodies of small relative size and perhaps caudal (Figs. 38 and 39). On the same surface was found the foot represented in Fig. 44. It is of small size relatively to the head, and was probably for swiming rather than walking. A few ovate bony scales were found with the bones, and probably belonged to this species (Fig. 41).

On the whole it seems certain that Hylerpeton must have been generically distinct from the other reptiles found with it, and it is probable that it was of more aquatic habits, swimming rather than walking; and feeding principally on fish. More perfect specimens would however be required in order to warrant any decided statement on these subjects. It is possible, as suggested by Prof. Owen, that the affinities of the animal may be with Archegosaurus rather than with any of the other coal reptiles; but I confess that my present impression is that it tends rather toward the genus Hylonomus. It may possibly be a link of connection botween the Microsauria and the Archegosauria.

EXPLANATION OF PLATE VI, FIGS. 32 TO 46 :

\section{Hylerpeton Dawsoni.}

Fig. 32-Portion of maxillary bone with teeth.

"33-Lower jaw and portions of skull.

" 34 and 35-Teeth magnified.

"36-Cast of pulp cavity of a tooth.

" 37-Cross section of tooth magnified.

"6 38 and 39-Bodies of Vertebræ.

"4 40-Fragments of ribs.

"41-Bony scale.natural size and magnified.

" 42 and 43-Surface of bone magnifled.

Bt 44-Foot.

"45-Bone of same magnified.

"46-Section of bone highly magnifiod: 


\section{XI.-Additional Reptiliain Remains.}

Plate VI, Figs. 47,48 , and 54 to 56.

Beside the species above described, Mr. O. C. Marsh, in 1861, added a new animal to the Joggins reptilian fauna; the Eosaurus Acadianus. The species is founded on two large biconcave vertebræ, in many respects resembling those of Ichthyosaurus, and indicating a reptile of greater size than any hitherto discovered in the coal, probably of aquatic habits, and possibly allied to the great Enaliosaurs or sea lizards of the mesozoic rocks. The specimen was found in a bed of shale belonging to group XXVI of my Joggins section, in the upper part of the middle coal measures, and about 800 feet above the bed which has afforded the remains described in previous sections. The beds belong to one of those intervals of shallow water deposition of sediment, which separate the groups of coal beds; and on one of them I found some years ago the footprints of Dendrerpeton.

The vertebræ of Eosaurus have been fully and ably described by Mr. Marsh in Silliman's Journal. Agassiz and Wyman regard their affinities as enaliosaurian. Huxley suggests the possibility, founded on his recent discovery of Anthracosaurus Russelli, that there may have been Labyrinthodont batrachians in the coal period with such vertebræ. However this may be, if the vertebræ were caudal as supposed by Mr. Marsh, since they are about $2 \frac{1}{2}$ inches in diameter, they would iudicate a gigantic aquatic reptile, furnished with a powerful swimming tail, and no doubt with apparatus for the capture and destruction of its prey, comparable with that of Ichthyosaumes.

In a bed of hard calcareous sandstone, some distance below that which afforded the animal just noticed, there occur great numbers of teeth and scales, referable in part to large sauroid fishes, but perhaps also in part to reptiles. One of these is a remarkable tooth obtained by Sir W. E. Logan in 1843, and represented in

* The remains were discovered in 1855 though not published till 1861. 
Fig. 47. It resembles externally the teeth of Baphetes, but its structure is almost precisely that of the teeth of the Lepidosteus, or bony pike of the St. Lawrence. Another tooth from the same bed, and with a similarly fluted surface, has a more complex labyrinthic structure, as seen in Fig. 48, which however represents only a small fragment. With these occur large round thin scales like those of Rhizodus, but also wrinkled bony plates resembling that which I have attributed to Baphetes. From the hardness of the rock it is difficult to extract perfect specimens of these remains, and no bones other than teeth and dermal scales have been found.

Under this head may be noticed the coprolitic matter which not infrequently occurs with the remains of reptiles, in the erect trees of the Joggins, and to which reference has already been made in previous sections. This fossil excrement is of a brown or fawn colour, and consists in great part of carbonate of lime, indicating probably that shells of snails or other mullusks formed a considerable part of the food of the smaller reptiles of the coal swamps. Some portions of it are filled with small bones apparently of Hylonomus Wymani. Other examples contain abundance of fragments of chitinous matter referable in part to Xylobius Sigillarice, the millipede of the coal; and in other instances to insects. Of the latter kind of remains the most interesting is an Eye, represented in Fig. 56. It must have belonged to an insect of considerable size, and with highly complex eyes, probably a neuropterous insect. As many as 250 facets are distinguishable in the fragment preserved, and the whole number in each eye may have amounted to 2000 . In size and form the facets resemble those of the eye of a common Canadian dragon fly of the genus Aeschra, but are a little smaller. In this and other coprolites, though abundance of minute chitinous fragments remain, no others are sufficiently perfect to be recognized. In one coprolitic mass a quantity of thick crust or shell occurs, which under the. microscope presents a minutely tubular and laminated appearance, resembling that of the shell of a crustacean rather than 
any other kind of structure with which I am acquainted. There may have been land-crabs in the coal period; but it is perhaps more likely that some one of the larger individuals of Dendrerpeton had been feeding on crustaceans in some pond or creek, before it fell into the pit in which it was entombed. It is however interesting to observe that no remains whatever of fishes have occurred in any of this coprolite or in the erect trees containing reptile bones, though such remains are very abundant in some of the associated beds. This fact confirms the inference deducible from other considerations, that the ground in which these open pits presented themselves, was not that of a very low swamp, liable to inundation, or very near to the sea or other bodies of water.

I may notice here certain very remarkable impressions, the origin of which I am at a loss to conjecture, but which may have had some relation to reptiles of the coal period. They occurred on the surface of a layer of grey sandstone about 60 feet above the bed containing the erect reptiliferous trees. This bed is one of a series of tlaggy layers on which occur, with vegetable fragments, tracks, possibly of Hylonomus, and rain-marks. The impressions now referred to were thus described by me in 1861 :

"They consist of rows of tranverse depressions, about an inch in length and one-fourth of an inch in breadth. Each trail consists of two of these rows running parallel to each other, and about six inches apart. Their direction curves abruptly, and they sometimes cross each other. From their position they were probably produced by a land or fresh-water animal-possibly a large Crustacean or gigantic Annelide or Myriapod. In size and general appearance they slightly resemble the curious Climactichnites of Sir W. E. Logan, from the Potsdam sandstone of Canada." To this I have only to add that the space between the rows of marks is slightly depressed and smoothed, as if with a heavy body, like that of a serpent, trailed along.

I have given in Fig. 54, as a supplement to the history of Dendrerpeton and Hylonomus, a diagram of the form of the skull and 
the character of the dentition, restored from actual specimens. This will serve further to illustrate the descriptions in previous sections.

In Fig. $65 \mathrm{I}$ have represented a group of scales from the throat of Dendrerpeton, as they lie beside the skull from which the greater part of the details in Fig. 54 are taken. It will be seen that these are elongated, oval, and very closely imbricated in rows diverging in a pinnate manner from a mesial line. They would give much protection, while not deficient in flexibility. It is probable however that Dendrerpeton could breathe by other means than the gulping of air by the contraction of the throat; and would therefore be less dependent on the action of the gular museles than the modern batrachians.

EXPLANATION OF PLATE VI, FIGS. 47, 48, AND 54 TO 56.1

Additional Reptilian Remains.

Fig. 47-Tooth of unknown reptile or fish, natural size, section natural size, and portion of section magnified, showing infolding of the enamel and arrangement of the dentine.

"48-Small segment of another tooth similar to the last in form and size, but more complex in the folding of the enamel.

" 54-Outer figure-Diagram of skull of Dendrerpeton, showing its size and general form, the appearance of the occipital condyles, and the arrangement of the double row of maxillary teeth and of the vomerine teeth.

" 54-Inner figure-Diagram of skull of Hylonomus, showing the arrangement of the single row of maxillary teeth and the patch of palatal teeth.

" 55-Bony scales of the throat of Dendrerpeton Acadianum, natural size. 


\section{Invertebrate Atr-Breathers.}

Plate VI., Figs. 49 to 53 , and 56 to 61 .

In addition to the insect whose eye has already been noticed, but two species of land Invertebrates have been recognized in the coal of Nova Scotia. One of these is a snail, Pupa vetusta, the other a gally-worm or millepede, Xylobius sigillarice. They are represented in the figures referred to at the head of this section, and have been fully described in the Journal of the Geological Society of London.

The first is the oldest known representative of the land snails, and so closely resembles the modern "chrysalis shells" of the genus Pupa, that I have not thought it desirable to refer it to a different genus, though the name Dendropupa has been proposed by Prof. Owen. Mr. J. S. Jeffreys and other eminent conchologists, who have seen the shell, concur in the opinion that it is a true Pupa; so that this genus, like Lingula and Nautilus, extends from the palæozoic to the modern times.

It may be described as a cylindrical shell, tapering to the apex, with a shining surface, marked with longitudinal rounded ridges. The whorls are eight or nine, rounded, and the width of each whorl is about half the diameter of the shell. The aperture is rather longer than broad; but is usually somewhat distorted by pressure. The margin of the lip is somewhat regularly rounded and is reflected outward. There are no teeth, but a slight indication of a ridge or ridges on the pillar lip, which may however be accidental. Length $\frac{3}{10}$ ths of an inch or a little more. It was first recognized by Dr. Gould of Boston, in specimens obtained by Sir C. Lyell and the writer at the Joggins.

This little shell is remarkable, not merely for its great antiquity, but also because it is separated by so wide an interval of time from any other known species of its race, there being no other Pulmonate known until we reach the Purbeck beds, and no true land snail until we reach the Tertiary. It is also worthy of remark, that while hundreds of specimens have been found, not only in 
the erect reptiliferous trunks but in a bed 1217 feet lower, and separated by twenty-one coal'beds, not any other species is found with it. It is very rare in modern times thus to find one species of snail in great abundance, without any others. More especially is this so when we can examine, as in this case, not only the decayed trunks in which the creature sheltered itself, but also the beds of mud into which its dead shells were washed. These facts present a striking instance either of that "iinperfection of the geological record", of which we hear so much, or of the solitary existence of a single species as a prophetic representative of future things, to be realized long after it had ceased to exist.

The lower bed, holding shells of 'Pupa vetusta, just mentioned, is a grey and greyish-blue under-clay, full of stigmarian rootlets; though without any coal or erect trees at its surface. It is 7 feet thick, with sandstone above and below. The shells occur very abundantly in a thickness of about two inches. They have been imbedded entire; but most of them have been crushed and flattened by pressure. They occur in all stages of growth; the young being, as is always the case in such shells, very different in general form from the adults. This bed is evidently a layer of mud deposited in a pond or creek, which afterward became silted up and carried sigillaroid trees. In modern swamps multitudes of shells occur in such places; and it is remarkable that in this case a single land shell should alone be found, without any trace of aquatic mollusks. The shells which occur in this bed are filled with the surrounding sediment. Those which occur in the erect Sigillarice, on the other hand, except when they are crushed and flattened, are filled with a deposit of brown calc-spar. I infer from this that the latter when buried contained the animals, and consequently that these lived or sheltered themselves in the hollow trees, as is the habit of many modern land snails.

The gally-worm of the coal period, Xylobius Sigillarice, must have existed in great numbers, as many layers in the erect trees are full of them. It probably lived in these decaying trunks just as its modern congeners do in similar places. As an air-breathing. 
animal, and subsisting on vegetable food, it cannot have lived in water, or even in very wet places; and this is one of the evidences which in this case point to a greater dryness of the coal swamps than has hitherto been supposed probable; it also shows the resemblance of the conditions of the areas of coal accumulation to those of modern forests.

With regard to the affinities of $X y$ lobius, its form and structure render certain its alliance with the Myriapods, and with the chilognathous division of them, or the gally-worms; but it is less certain to which of the families of the recent gally-worms it belongs, if to any of them. I have however little doubt that if it existed as a recent animal, it would go into the tribe Bizonia of Newport, and probably into the family of Iutidoe, to the typical genus of which it bears a strong resemblance in such points as can be made out. The oldest Myriapod previously known is, I believe, the Geophilus proavus, Münster, of the Jurassic period*.

EXPLANATION OF PL. VI, FIGS. 47 To 53, AND 56 то 61.

\section{Invertebrate Air-Breathers.}

Fig. 49.-Pupa Vetusta, natural size.

"50.- " " magnified.

"51.-Pupa Vetusta, apex magnified.

"52.- " " $"$ sculpture of surface magnified.

"53.- " " cellular structure of shell highly magnified.

"56.-Eye of an Insect, natural size and magnified, and three ocelli highly magnified.

"57.-Xylobius Sigillaria, Anterior segments magnified.

"58.- " " $"$ natural size.

"59.- " " 6 part of one of the posterior segments magnified.

"60.- " " " caudal extremity magnified.

"61. " " " head magnified, showing the eyes.

- Pictet, Palæontologie, Vol. 11, p. 405. 
XIII.-Characters of the Animals Described in this Paper.

To facilitate comparisons, I propose in this section to give an abstract of the leading structural points which may serve to distinguish the animals described in this paper from each other, and from such new species as may be discovered either in Nova Scotia or elsewhere. The characters given must necessarily be incomplete, and I shall confine myself to points distinctly ascertained and likely to be met with in any additional specimens which may be discovereà.

\section{Province.-VERTEBRATA。 \\ Class.-Reptilia. \\ Order.-Microsauria。 \\ Genus.-Hylonomus.}

Reptiles or batrachians; with simple teeth in one series; biconcave vertebræ with arches anchylosed to them; ribs long and bent; limbs developed for walking; cranial bones smooth or nearly so; body protected below with oval or ovate bony scales, and above with horny scales and other appendages.

1. Hylonomus Lyelli, Dawson.-Teeth elongated, conical, thirty-six in each side of the jaw; larger toward the anterior part of the lower jaw; length of lower jaw .7 inch; limbs well developed, especially the posterior pair; bony scales oval; body above with imbricated horny scales, and rows of angular and bristly points.

2. Hylonomus aciedentatus, Dawson.-Teeth of maxillary and mandible thick wedge form, or nearly round at base and flattened to an edge at top. Teeth of intermaxillaries cylindric, bluntly pointed, and with spiral furrows at the point. Number of teeth about forty on each side of jaw; length of lower jaw about 1 inch. Size more than twice that of $H$. Lyelli. Dermal covering so far as known, similar, but the parts large in proportion.

3. Hylonomus Wymani, Dawson.-Teeth obtusely conical, about 
twenty in each side of the jaw; length of lower jaw about .25 inch. Vertebræ elongated; size much smaller than that of $H$. Lyelli. Bony scales small and rounded, body above probably clothed in imbricated horny scales.

\section{Order.-Labyrinthodontia.}

Genus.-Baphetes.

Baphetes planiceps, Owen.-Teeth conical, hooked, striated longitudinally, and with inflected and convoluted cement; in two series; the inner. of larger size. Cranial bones much corrugated. Head broad; breadth in front of orbits 6 inches; length from this line to front of snout $3 \frac{1}{2}$ inches. Probably a dermal covering of corrugated bony scales.

\section{Genus.-Dendrerpeton.}

Batrachians with a double series of teeth; the outer simple and flattened conic, the inner conical with inflected folds of cement. Teeth also on the vomer. Bones of skull corrugated; body protected below with long ovate or rhomboid bony scales, and above with imbricated horny scales. Form elongated, fore limbs largest, tail natatory, vertebræ biconcave, neural arches and bodies ossified.

1. Dendrerpeton Acadianum, Owen.-Inner teeth straight conical ; outer teeth short and obtuse. Length of head 2.75 inches, breadth at orbits about 2 inches, distance of orbits .7 inch. Length one to two feet.

2. D. Oweni, Dawson.-Teeth slender and hooked, and cement of inner teeth more perfectly inflected. Length of skull 1.2 inch, distance of orbits about .5 inch; length one foot or less.

\section{Order.-Archegosauria? \\ Genus.-Hylerpeton.}

Hylerpeton Dawsoni, Owen.-Teeth simple, bluntly conical, with large pulp cavity; about 13 in one side of the jaw. Two of the anterior teeth of the upper jaw twice as large as the others, 
and deeply sunk in the jaw. Length of lower jaw 1.3 inch Bones of skull puncto-striate. Limbs unknown, probably natatory.

ShDis InCERTæ.

Genus.-Eosaurus.

Eosaurus Acadianus, Marsh.-Known by two biconcave vertebræ 2.4 inches in diameter and much resembling the caudal vertebræ of Ichthyosaurus-see paper by Mr. Marsh, Silliman's Journal, vol. xxxiv.

\section{Province.-ARTICULATA.}

Sub Class.-Mrriapoda.

Order.-Chilognatha.

Genus.-XYLoBius.

Xylobius Sigillarice, Dawson.-Body crustaceous, elongate, one to two inches in length, articulate; when recent, cylindrical or nearly so, rolling spirally. Feet small, numerous; segments 30 or more; anterior segments smooth, posterior with transverse wrinkles, giving a furrowed appearance. In some specimens traces of a series of lateral pores or stigmata. Labrum? quadrilateral, divided by notches or joints into three portions. Mandibles two-jointed, last joint ovate and pointed. Eyes ten or more on each side.

\section{Province.-MOLLUSCA. \\ Class.-Gasteropoda.$$
\text { Order.-Pulmonata. }
$$$$
\text { Genus.-PuPa. }
$$

Pupa Vetusta, Dawson.-Cylindrical, tapering toward the apex; surface shining, minutely marked with longitudinal ridges; whorls 8 or 9 , rounded, width of each equal to half the diameter of the shell; aperture rather longer than broad; outer lip regularly rounded and somewhat reflected; pillar lip straightened above, rounded below. Edentulous or with faint ridges on columella? Length .3 inch or a little more. 


\section{XIV.-Concluding Remarks.}

Having finished the work which I proposed to myself, in illus:tration of the air-breathers of the coal period in Nova Scotia, it now remains to mention a few general thoughts which have arisen. in connection with the animals which have been described.

I have endeavored, in the frontispiece, to present to the eye the forms and attitudes of these creatures. In doing so as little latitude as possible has been allowed to the imagination, and the structural points indicated by the bones and skin actually found, have been adhered to as closely as practicable. On the left hand Baphetes planiceps is seen emerging with a ganoid fish in its jaws. Next Dendrerpeton Acadianum is represented slowly walking up the inclined shore, and leaving its hand-like footprints thereon. A little farther up Hylonomus Lyelli is leaping in pursuit of an insect, and Hylonomis Wymani stands a little more in the foreground, while Hylerpeton Dawsoni is disporting itself in the water in front. I am quite aware that the form and action given to Hylonomus are at variance with the views of its nature, which would ally it with Archegosaurus; but, as stated above, I cannot refuse my belief to the testimony of the bones themselves, which prove a development of the hind limbs not likely to have been associated with an elongated body and natatorial tail, and pointing to saltatory motion on land, and perhaps frog-like swimming in the water. In the middle ground of the picture I have placed a bank of soil, showing a section of a hollow trunk similar in situation to those in which the reptile bones of the Joggins occur, and on this bank and in the distance, I have endeavored to give some of the characteristic forms of the vegetation of the period: Ferns, Cordaites, Sigitlaria, Lepidendron, Lepidophtoios, and Calamites.

It has recently been a favorite view with some writers on this subject, that coal beds may have been formed in shallow salt water, and that Sigillarice may have grown in such places, like mangroves. It will be seen from the frontispiece, that I do not believe- 
in this theory of the formation of coal, but on the contrary adhere to the opinion which I have formerly maintained, that the coal beds and under-clays are of the nature of peaty soils. In no part of the world are the coal measures better developed or more fully exposed than in the coast sections of Nova Scotia and Cape Breton; and in these, throughout their whole thickness, no indication has been found of any of the marine fossils of the lower carboniferous limestone. Abundant remains of fishes occur, but these may have frequented estuaries, streams and ponds, and the greater part of them are small ganoids which, like the modern Lepidosteus and Amia, may have been specially fitted by their semi-reptilian respiration, for the impure waters of swampy regions. Bivalve mollusks also abound; but these are all of the kinds to which I have given the generic name Naiadites, and Mr. Salter those of Anthracomya and Anttracoptera. These shells are all distinct from any known in the marine limestones. Their thin edentulous valves, their structure consisting of a wrinkled epidermis, a thin layer of prismatic shell and an inner layer of sub-nacreous shell composed of obscure polygonal cells, all remind us of the Anodons and Unios.* A slight notch in front, noticed by Salter, as possibly byssal, concurs with their mode of occurrence in rendering it probable that,like mussels in modern estuaries, they attached themselves to floating or sunken timber. They are thus removed, both in structure and habit, from truly marine species; and if not actually of the family Unionidce, must have been fresh-water or brackishwater mussels closely allied to this family. The crustaceans (Eurypterus,Diplostylus,Cyprids,) and the worm shell (Spirorbis) $\dagger$

* The microscopic structure of these shells is well preserved, and presents some differences of detail which I hope at a future time to illustrate.

† The idea of some Palæobotanists, that these so-called Spirorbes are fossil parasitic plants, is obviously a mistake. They are calcareous shells, and present under the microscope a prismatic cellular structure, with numerous minute tubuli, in the manner of the shells of modern Serpule and Spirorbes. In Nova Scotia I have seen Estheria only in the lower coal formation. 
found with them, are not necessarily marine, though some of them belonged probably to brackish water, and they have not yet been found in those carboniferous beds deposited in the open sea. There is thus in the whole thickness of the middle coal measures of Nova Scotia, a remarkable absence at least of open sea animals; and if, as is quite probable, the sea inundated at intervals the areas of coal accumulation, the waters must have been shallow and to a great extent land-locked, so that brackish-water rather than marine animals inhabited them.

On the other hand, there are in these coal measures, abundant evidences of land surfaces ; and sub-aeriel decay of vegetable matter in large quantity is proved by the occurrence of the mineral charcoal of the coal itself, as I have elsewhere shown.* The erect trees which occur at so many levels, also imply sub-aerial decay. A tree imbedded in sediment and remaining under water, could not decay so as to become hollow and deposit the remains of its wood in the state of mineral charcoal within the hollow bark. Yet this is the case with the greater part of the erect sigillaria which occur at more than 20 levels in the Joggins section. Nor could such hollow trunks become repositories for millipedes, snails and reptiles, if under water. On the other hand, if, as seems necessary to explain the character of the reptiliferous erect trees, these remained dry or nearly so in the interior, this would imply not merely a soil out of water, but comparatively well drained; as would indeed always be the case, when a flat resting on a sandy subsoil was raised several feet above the level of the water. Farther, though the peculiar character of the roots of Sigitlarioe and Calamites may lend some countenance to the supposition that they could grow under water or in water-soaked soils, this will not apply to coniferous trees, to ferns, and other plants, which are found under circumstances which show that they grew with the Sigillaria.

In the coal measures of Nova Scotia, therefore, while marine

* Journal of Geological Surrey, rol. XV. 
conditions are absent, there are ample evidences of fresh-water or brackish-water conditions, and of land surfaces, suitable for the air-breathing animals of the period. Nor do I believe that the coal measures of Nova Scotia were exceptional in this respect. It is true that in Great Britain evidences of marine life do occur in the coal measures; but not, so far as I am aware, in circumstances which justify the inference that the coal is of marine origin. Alternations of marine and land remains, and even mixtures of these, are frequent in modern submarine forests. When we find, as at Fort Lawrence in Nova Scotia, a modern forest rooted in upland soil forty feet below high-water mark, * and covered with mud containing living Tellinas and Myas, we are not justified in inferring that this forest grew in the sea. We rather infer that subsidence has occurred. In modern salt marshes it is not unusual to find every little runnel or pool full of marine shellfish, while in the higher parts of the marsh land plants are growing; and in such places the deposit formed must contain a mixture of land plants and marine animals with salt grasses and herbagethe whole in situ. $\dagger$

These considerations serve, I think, to explain all the apparently anomalous associations of coal plants with marine fossils; and I do not know any other arguments of apparent weight that can be adduced in favor of the marine origin of coal, except such as are based on misconceptions of the structure and mode of growth of sigillaroid trees and of the stratigraphical relations of the coal itself. . It is to be observed, however, that while I must maintain

* Jourual of Geological Society, vol. XI,

f In the marshes at the mouth of Scarborough River, in Maine, channels not more than a foot wide, and far from the sea, are full of Mussels and Myæ; and in little pools communicating with these channels there are often many young Limuli, which seem to prefer such places, and the cast off shells and other remains of which may become imbedded in mud and mixed with land plants, just as in the shales of the coal measures.

$\ddagger$ It is unfortunate that few writers on this subject have combined with the knowledge of the geological features of the coal, a sufficient acquain- 
the essentially terrestrial character of the ordinary coal and of its plants, I have elsewhere admitted that cannel coals and earthy bitumen present evidences of sub-aquatic deposition; and have also abundantly illustrated the facts that the coal plants grew on swampy flats, liable not only to river inundations, but also to subsidence and submergence.* In the oscillation of these conditions it is evident that Sigillarioe and their contemporaries must often have been placed in conditions unfavorable or fatal to them, and when their remains are preserved to us in these conditions, we may form very incorrect inferences as to their" mode of life. Farther, it is be observed that the conditions of submergence and silting up which were favorable to the preservation of specimens of Sigillarioe as fossils, must have been precisely those which were destructive to them as living plants; and on the contrary that the conditions in which these forests may have flourished for centuries, must have been those in which there was little chance of their remains being preserved to us, in any other condition at least than that of coal, which reveals only to careful microscopic examination the circumstances, whether aerial or aquatic, under which it was formed.

It is also to be observed that, in conditions such as those of the coal-formation, it would be likely that some plants would be

tance with the phenomena of modern marshes and swamps, and with the conditions necessary for the growth of plants such as those of the coal. It would be easy to show, were this a proper place to do so, that the "swells," "rock-faults," splitting of beds, and other appearances of coal seams, quite accord with the theory of swamp accumulation; that the plants associated with Sigillarice could not have lived with their roots immersed in salt water; that the chemical character of the underclays implies drainage and other conditions impossible under the sea; that the composition and minute structure of the coal are incompatible with the supposition that it is a deposit from water, and especially from salt water ; and that it would be more natural to invoke wind-driftage as ¿ mode of accumulation for some of the sandstones, than water-driftage for the formation of the coal.

* Journal of Geol. Socy., vols. X and XV and "Acadian Geology." 
specially adapted to occupy newly emerged flats and places liable to inundation and silting up. I believe that many of the Sigillarice, and still more eminently the Calamites, were suitable to such stations. There is direct evidence that the nuts of Sigillarice (Trigonocarpa) were drifted extensively by water over submerged flats of mud. Many Cardiocarpa were winged seeds which may have drifted in the air. The Calamites may, like modern Equise$t a$, have produced spores with elaters capable of floating them in the wind. One of the thinner coals at the Joggins is filled with spores or spore-cases that seem to have carried hairs on their surfaces, and may have been suited to such a mode of dissemination. I have elsewhere proved that at least some species of Calamites, were by their mode of growth admirably fitted for growng amid accumulating sediment and for promoting its accumulation.

These and other facts to be ascertained only by a careful and minute study of the coal formation and its fossils, are essential to a right understanding of the complicated conditions involved in the growth of these great deposits; and notwithstanding the immense mass of facts which has been collected, there is still no department of geology more encumbered with crucle hypotheses and hasty generalizations, than that which relates to the history of the carboniferous period.

The reptiles of the coal formation are probably the oldest known to us, and possibly, though this we cannot affirm, the highest pro. ducts of creation in this period. Supposing, for the moment, that they are the highest animals of their time, and what is still less likely, that those which we know are a fair average of the rest, we have the curious fact that they are all carnivorous, and the greater part of them fitted to find food in the water as well as on the land. The plant feeders of the period, on the land at least, are all invertebrates, as snails, millepedes, and perhaps insects. The air-breathing vertebrates are not intended to consume the exuberant vegetable growth, but to check the increase of its animal enemies. Plant life would thus seem to have had in every way the advantage. The millepedes probably fed only on roots 
and decaying substances-the snails on the more juicy and succulent plants growing in the shadow of the woods. While, moreover, the vegetation of the coal swamps was most abundant, it was not, on the whole, of a character to lead us to suppose that it supported many animals. Our knowledge of the flora of the coal swamps is sufficiently complete to exclude from them any abundance of the higher phænogamous plants. We know little, it is true, of the flora of the uplands of the period; but when we speak of the coal formation land, it is to the flats only that we refer. The foliage of the plants on these flats, with the exception of that of the ferns, was harsh and meagre, and there seem to have been no grasses or other nutritious herbaceous plants. These are wànts of themselves likely to exclude many of the higher forms of herbivorous life. On the other hand there was a profusion of large nut-like seeds, which in a modern forest would probably have afforded subsistence to squirrels and similar animals. The pith and thick soft bark of many of the trees must at certain seasons have contained much nutritive matter, while there was certainly sufficient material for all those insects whose larvæ feed on living and dead timber, as well as for the creatures that in turn prey on them. It is remarkable that, perhaps with the exception of a very few European insects, no animals fitted to avail themselves of these vast stores of food have been discovered in the coal. The question: "What may have fed on all this vegetation?" was never absent from my mind in all my explorations of the Nova Scotia coal sections; but no trace of any creature other than those already mentioned has ever rewarded my search. In Nova Scotia it would seem that a single snail and a single gally-worm were the sole links of connection between the plant creation and air-breathing vertebrates. Is this due to the paucity of the fauna, or the imperfection of the record? The fact that a few erect stumps have revealed nearly all the air-breathers yet found, argues strongly for the latter cause; but there are some facts bearing on the other side.

Our gally-worm, if, like its modern relatives, hiding in crevices of wood in forests, was one of the least likely animals to be found 
in aqueous deposits. The erect trees gave it its almost sole chance of preservation. Pupa vetusta is a small species, and its shell very thin and fragile, while it probably lived among thick vegetation. Further it occurs in great abundance in the sigillaria stumps, and also in a bed separated from these by a thickness of 1217 feet, including 21 coal seams, having an aggregate thickness of about 20 feet, 3 beds of bituminous limestone of animal origin, and perhaps 20 beds holding Stigmaria in situ,or erect Sigillarioe and Calamites. The lapse of time implied by this succession of beds, nnany of them neccessarily of very slow deposition, must be very great, though it would be mere guess work to attempt to resolve it into years. Yet long though this interval must have been, Pupa vetusta lasted without one iota of change through it all ; and more remarkable still, was not accompanied by any other mollusk of its family. Where so many specimens occur, and in situations so diverse, without any additional species, the inference is strong that no other of similar habits existed. If in any of those sub-tropical islands, whose climate and productions somewhat resemble those of the coal period, after searching in and about decaying trees, and also on the bars upon which rivers and lakes drifted their burdens of shells, we should find only a single species, but this in very great numbers, we would surely conclude that other species, if present, were very rare.

Again, footprints referrible to Dendrerpeton occur in the lower coal measures below the marine limestones, in the middle coal measures, and in the upper coal formation, separated by a thickness of beds which may be estimated at 15,000 feet, and certainly representing a vast lapse of time. Did we know the creature by these impressions alone, we might infer its continued existence for all this great length of time; but when we also find its bones in the principal repositories of reptile remains, and in company with the other creatures found with it, we satisfy ourselves that of them all it was the most likely to have left its trail in the mud flats. We thus have reason to conclude that it existed alone during this period, in so far as its especial kind of habitat was con. 
cerned; though there lived with it other reptiles, some of which, haunting principally the woods, and others the water, were less likely to leave impressions of their footprints. These may be but slight indications of truth, but they convey strong impressions of the persistence of species, and also of the paucity of species belonging to these tribes at the time.

Every fact of this kind is at present regarded in its bearings on the probable origin of species, and on the questions of independent creation or of derivation by natural selection, or by some other secondary law. Naturalists have set themselves to discover the philosopher's stone which can transmute the viler into the more exalted species. They will probably fail as others have failed before, but may at least hope to elicit some law of succession or occurrence of living creatures, and to settle more clearly than heretofore what should be regarded as natural species, as distinct from mere races and varieties. It may perhaps be found, after all, that the question whether the creative force manifested itself in calling certain species into existence from nothing, from dead matter, or from previously organized matter, whether by an instant and miraculous act, by more sudden natural cliange, or by slow and gradual processes, is insoluble by us; or that all or many of these modes may have been concerned in making living beings what they are; but of this every sound thinker must be convinced, that if not originating in distinct creative acts, species as we have them must be due to causes vastly more recondite and complex than the present adrocates of derivation suppose. Nor can even the transmutationist altogether get rid of the miracle of creation; though he may push it back to as great a distance as possible. Some creative foree must always precede law, and this even when the theorist goes so far as to derive all things from a concuurse of atoms; or, more venturous still, dispenses even with atoms, and resolves ail that he knows into an aggregate of conflicting yet mutually convertible forces. It is scarcely to be supposed that any member even of this last school, will choose to plunge into the two-fold absurdity of supposing that forces are themselves pro- 
duced by nothing but the law of their own action, and produce all things by their action on nothing but themselves.

If we could affirm that the air-breathers of the coal period were really the first species of their several families, they might acquire additional interest by their bearing on this question of origin of species. We cannot affirm this; but it may be a harmless and not uninstructive play of fancy to suppose for a moment that they actually are so, and to inquire on this supposition as to the mode of their introduction. Looking at them from this point of view, we shall first be struck with the fact that they belong to all of the three great leading types of animals which include our modern air-breathers-the Vertebrates, the Articulates, and the Mollusks. This at once excludes the supposition that they can all have been derived from each other, within the limits of the coal period. No transmutationist can have the hardihood to assert the convertibility, by any direct method, of a snail into a millipede, or of a millipede into a reptile. The plan of structure in these creatures is not only different but contrasted in its most essential features. It would be far more natural to suppose that these animals sprang from aquatic species of their respective types. We should then seek for the ancestors of the snail in aquatic gasteropods, for those of the millipede in worms or crustaceans, and for those of the reptiles in the fishes of the period. It would be easy to build up an imaginary series of stages, on the principle of natural selection, whereby these results might be effected; but the hypothesis would be destitute of any support from fact, and would be beset by more difficulties than it removes. Why should the result of the transformation of water snails breathing by gills be a Pupa? Would it not much more likely be an Auricula or a Limnea? It will not solve this difficulty to say that the intermediate forms became extinct and so are lost. On the contrary they exist to this day, though they were not, in so far as we know, introduced so early. But negative evidence must not be relied on; the record is very imperfect, and such creatures may have existed though unknown to us. It may be answered that 
they could not have existed in any considerable numbers, else some of their shells would have appeared in the coal formation beds, so rich in crustaceans and bivalve mollusks. Further, the little Pupa remained unchanged during a very long time, and shows no tendency to resolve itself into anything ligher or to descend to anything lower. Here, if anywhere, in what appears to be the first introduction of air-breathing invertebrates, we should be able to find the evidences of transition from the gills of the prosobranchiate and the crustacean to the air-sac of the pulmonate and the tracher of the millipede. It is also to be observed that many other structural changes are involved, the aggregate of which makes a pulmonate or a millipede different in every particular from its nearest allies among gill-bearing gasteropods or crustaceans.

It may be said however that the links of connection between the coal reptiles and the fishes are better established. All the known coal reptiles have leanings to the fishes in certain characters; and in some, as in Archegosaurus, these are very clnse. Still the interval to be bridged over is wide, and the differences are by no means those which we should expect. Were the problen given to convert a ganoid fish into an Archegosaume or Dendrerpeton, we should be disposed to retain unchanged such characters as would be suited to the new habits of the creature, and to change only those directly related to the objects in view. We should probably give little attention to differences in the arrangement of skull bones, in the parts of the vertebræ, in the external clothing, in the microscopic structure of the bone, and other peculiarities for serving similar purposes by organs on a different plan, which are so conspicuous so soon as we pass from the fish to the batrachian. It is not in short an improvement of the organs of the fish that we witness so much as the introduction of new organs. The foot of the batrachian, bears perhaps as close a relation to the fin of the fish as the screw of one steamship to the paddle wheel of another, or as the latter to a carriage wheel; and can be just 
as rationally supposed to be not a new instrument but the old one clianged.

Again, our reptiles of the coal do not constitute a continuous series, nor is it possible that they can all, except at widely different times, have originated from the same source. To suppose that Hylonomus grew out of Dendrerpeton or Baphetes, and Eosaurus out of eitlier, startles us almost as much as to suppose that Baphetes grew out of Rhizodus, or Hylonomus out of Paloconiscus. It either liappened, for some unknown reason, that many kinds of fishes put on the reptilian guise in the same period, or else the vast lapse of ages required for the production of a reptile from a fish, must be indefinitely increased for the production of many dissimilar reptiles from each other; or on the other hand we must suppose that the limit between the fish and reptile being once overpassed, a facility for comparatively rapid changes became the property of the latter. Either supposition would, I think, contradict such facts bearing on the subject as are known to us.

We commenced with supposing that the reptiles of the coal might possibly be the first of their family, but it is evident from the above considerations, that on the doctrine of natural selection, the number and variety of reptiles in this period would imply that their predecessors in this form must have existed from a time earlier than any in which even fishes are known to exist; so that if we adopt any hypothesis of derivation, it would probably be necessary to have recourse to that which supposes at particular periods a sudden and as yet unaccountable transmutation of one form into another; a view which in its remoteness from anything included under ordinary natural laws, does not materially differ from that currently received idea of creative intervention, with which, in so far as our coal reptiles can inform us, we are for the present satisfied.

There is one other point which strikes the naturalist in considering these animals, and which has a certain bearing on such hypothesis. It is the combination of various grades of reptilian types 
in these ancient creatures. It has been well remarked by Hugh Miller, and more fully by Agassiz, that this is characteristic of the first appearance of new groups of animals. Now selection, as it acts in the hands of the breeder, tends to specialization; and ratural selection, if there is such a thing, is supposed to tend in the same direction. But when some distinctly new form is to be introduced, an opposite tendency seems to prevail, a sort of aggregation in one species of characters afterward to be separated and manifested in distinct groups of creatures. The introduction of such new types also tends to degrade and deprive of their higher properties previously existing groups of lower rank. It is easy to perceive in all this, law and order, in that higher sense in which these terms express the will and plan of the Supreme Mind, but not in that lower sense in which they represent the insensate operation of blind natural forces.

Humble though the subjects of this paper are, we see in them the work of Supreme Intelligence, introducing new types upon the scene and foreshadowing in them those higher forms afterward to be created. It is this, their Divine origin, and the light which they throw on the plan and order of the creative work, of which we ourselves form a part, that gives them all their interest to us. They are the handiwork of our Father and our God, traces of his presence in primeval ages of the earth, evidences of the unity of his plan and pledges of its progressive nature; adding their feeble voices to the testimony of revelation in respect to the history of creation in its earlier stages, and to the carrying on of that plau which still involves the extinction of many things from the present world, and the elevation of others into new and glorious manifestations. Their place in the system of nature and in the order of the world's progress, their uses in their own time and their relations to other beings as parts of the great cosmos, are the points that chiefly interest us : and if any one desires to understand more in detail, how they were created, we wish him all success in his inquiries, but warn him not to suppose that this great mystery is to be solved by a reference 
hierely to material agencies, apart from that Spiritual Power who is the essence of forees, the origin of laws.

While these sheets were passing through the press, I have for the first time been enabled to study Von Meyer's plates of the coal reptiles of Germany. They eonfirm my previous impression of the generic and probably family distinetness of Dendrerpeton and Irylonomus from Archegosauries. The former of the two gener't named is however that which approaches most nearly to Von Meyer's genus. The arrangement of the tecth in A. latirostris mueh resembles that in Dcudicrpeton, and the scales on the throat and belly are similar in form and arrangement. The form of the skull, and the proportions of its bones, are, however, quite different in the two genera. The vertebræ of Dendrerpeton are also mueh more perfectly ossified, its ribs very much larger and more bent, and its limbs much larger and adapted for supporting the body on the land. Archegosaurus must have been in all respects more ichthyoid and aquatic than any of the species of Dendrerpeton or Hylonomus.

The skull figured by Von Meyer under the name of Sclerocepthatus Mauscri, may have belouged to an animal more nearly allied to Dendrerpeton than were the speeies of Archcgosaurus.

If animals of the type of Archegosaurus existed in the coal period in Nova Scotia, their remains would not be likely to occur in such repositories as the ereet trunks of Sigillarie, but only in strictly sub-aqueous deposits. 




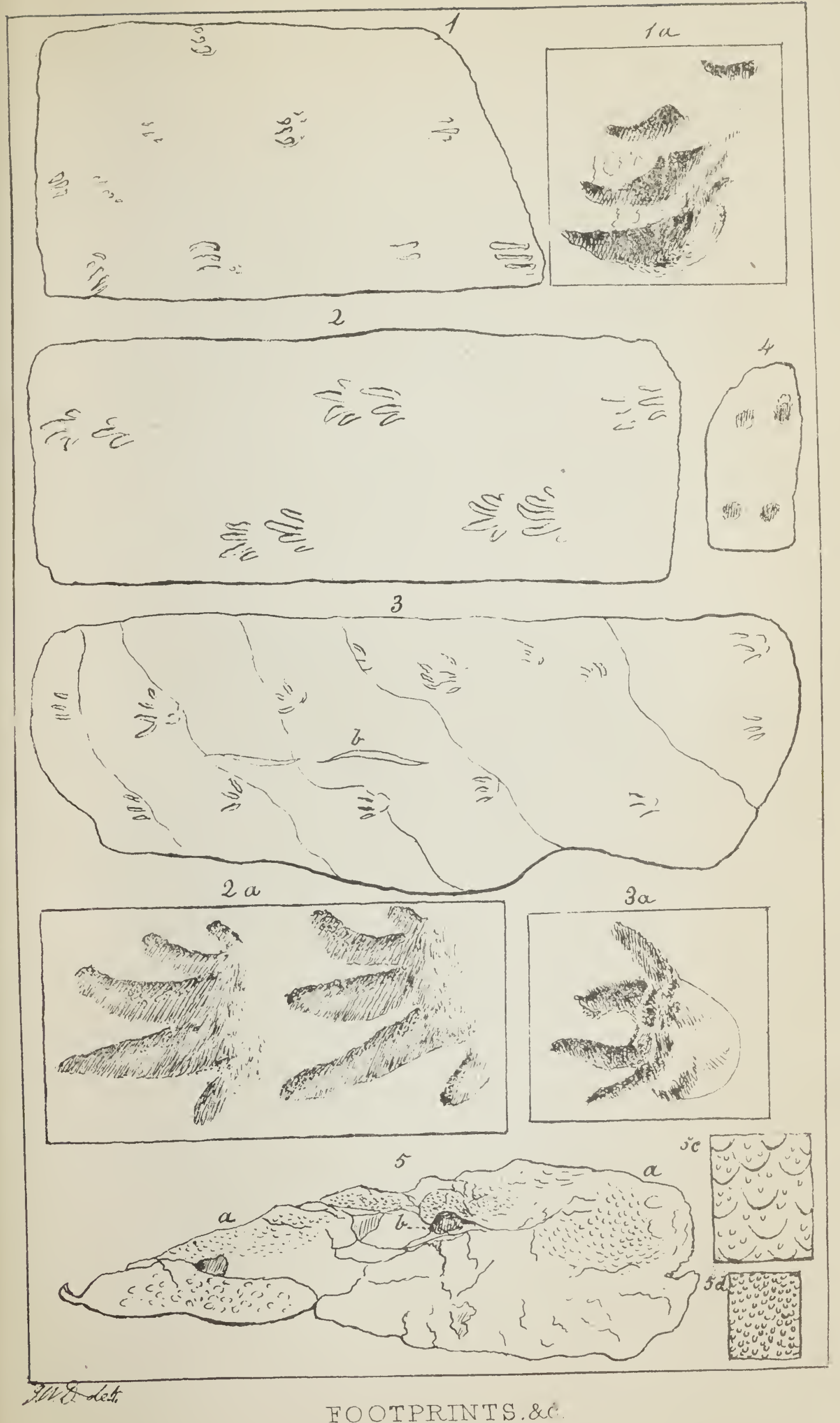



PL.II

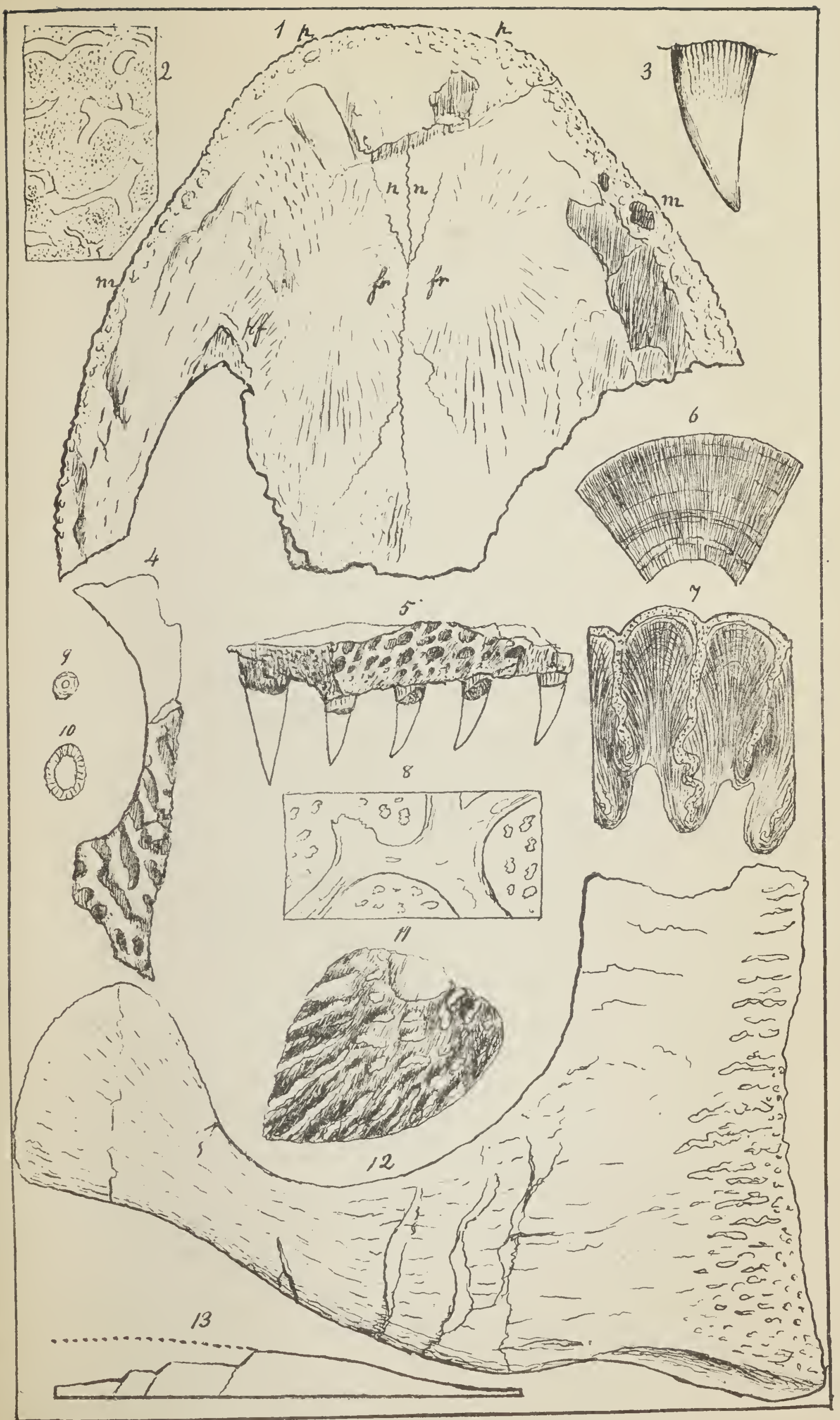

Insud!

BAPHETES PLANICEPS, OMen, 

PT T]

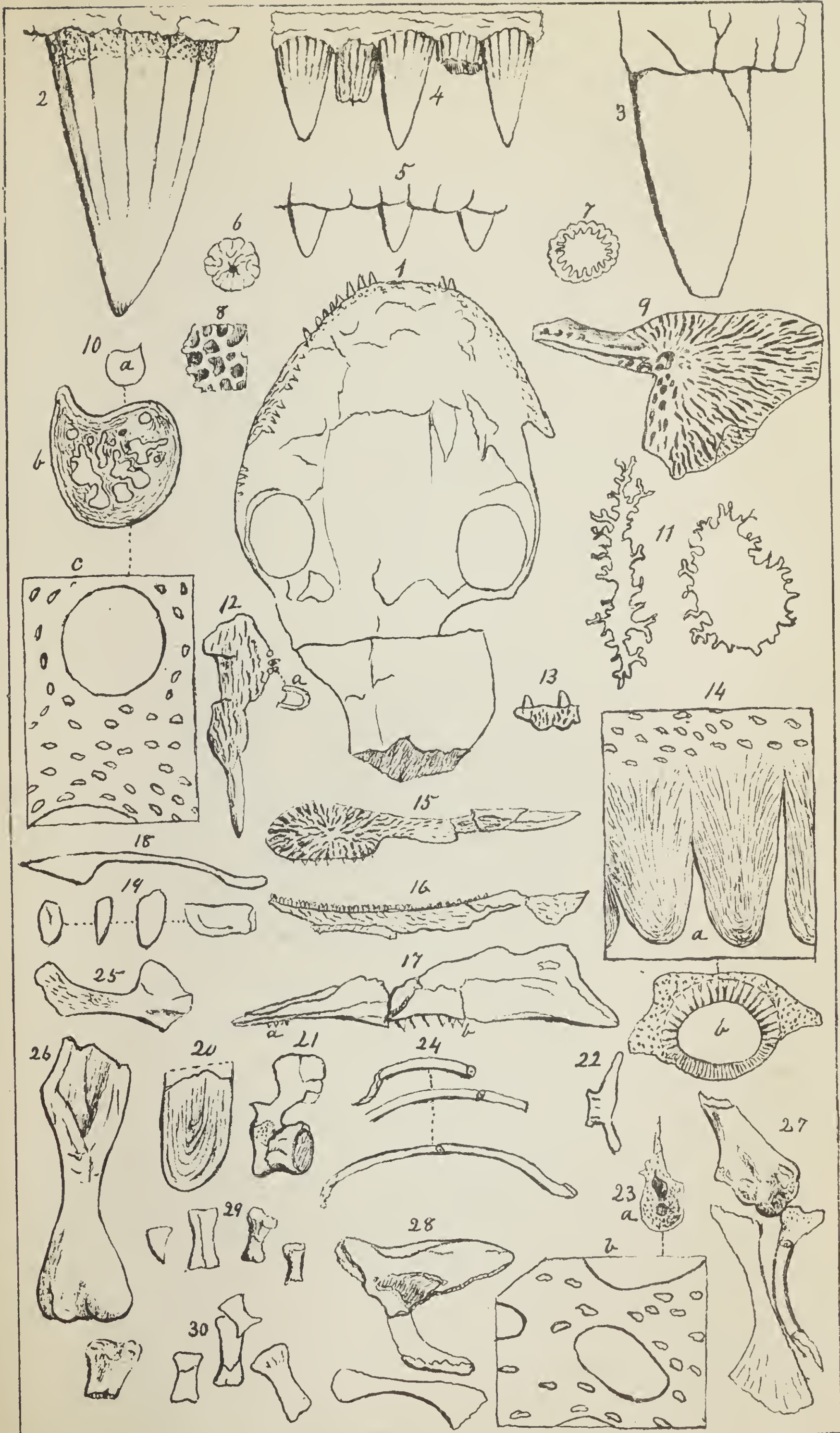





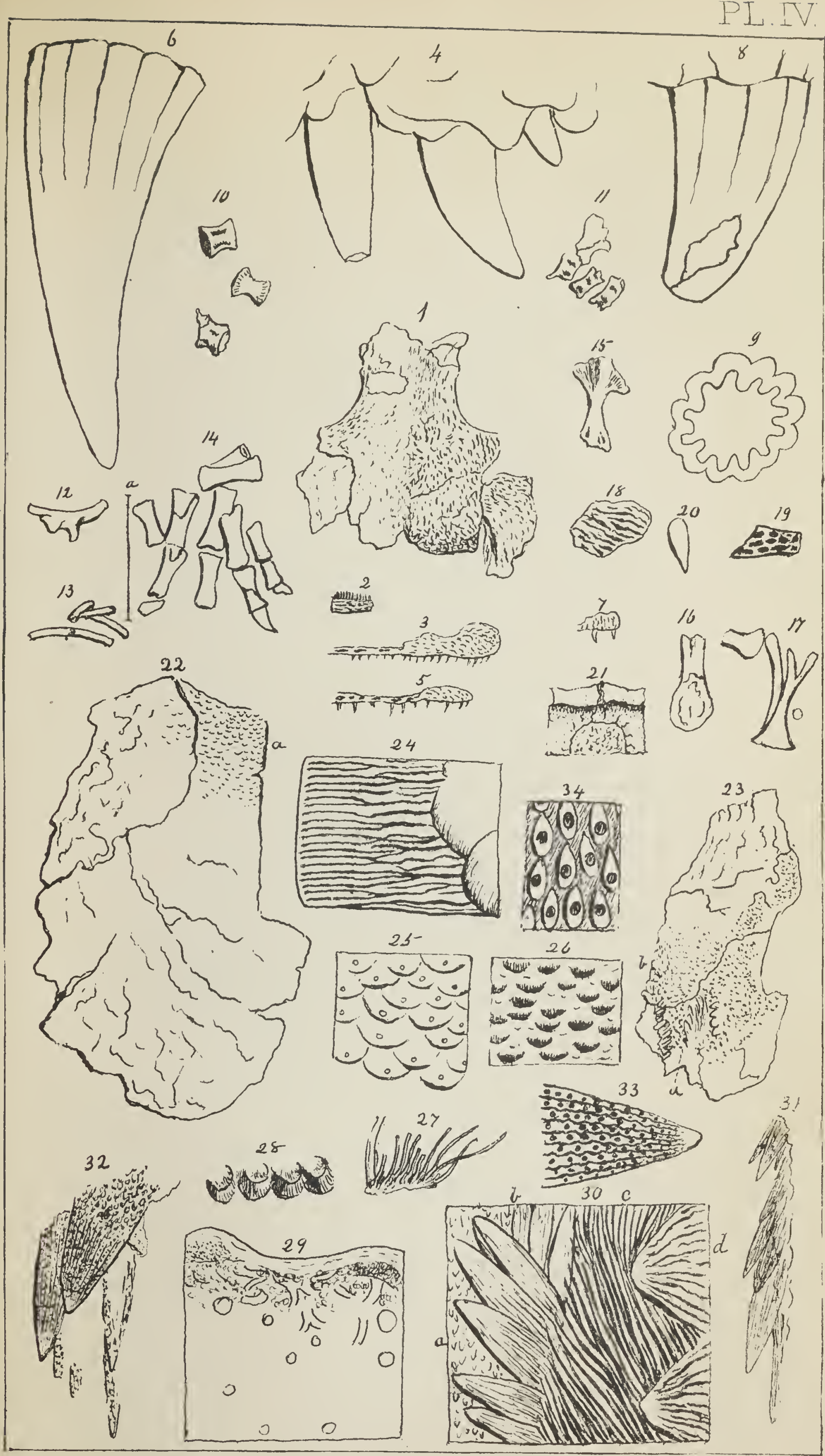

Lis dut

DENDRERPETON OWENI, Dawson, Figs.7To ?I.

Shin \& Hornv Scales (Figs. 22 \&c.) 



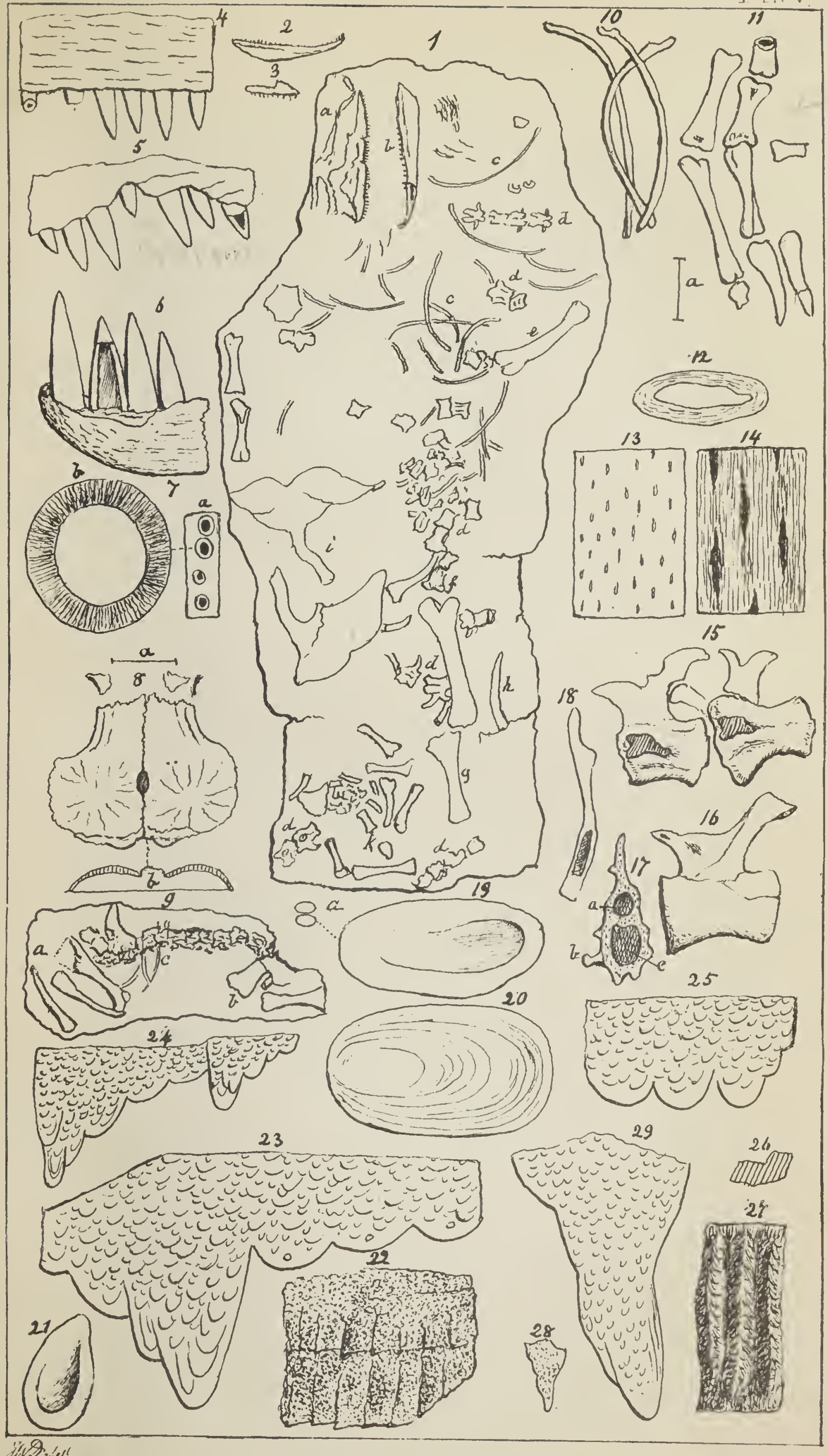





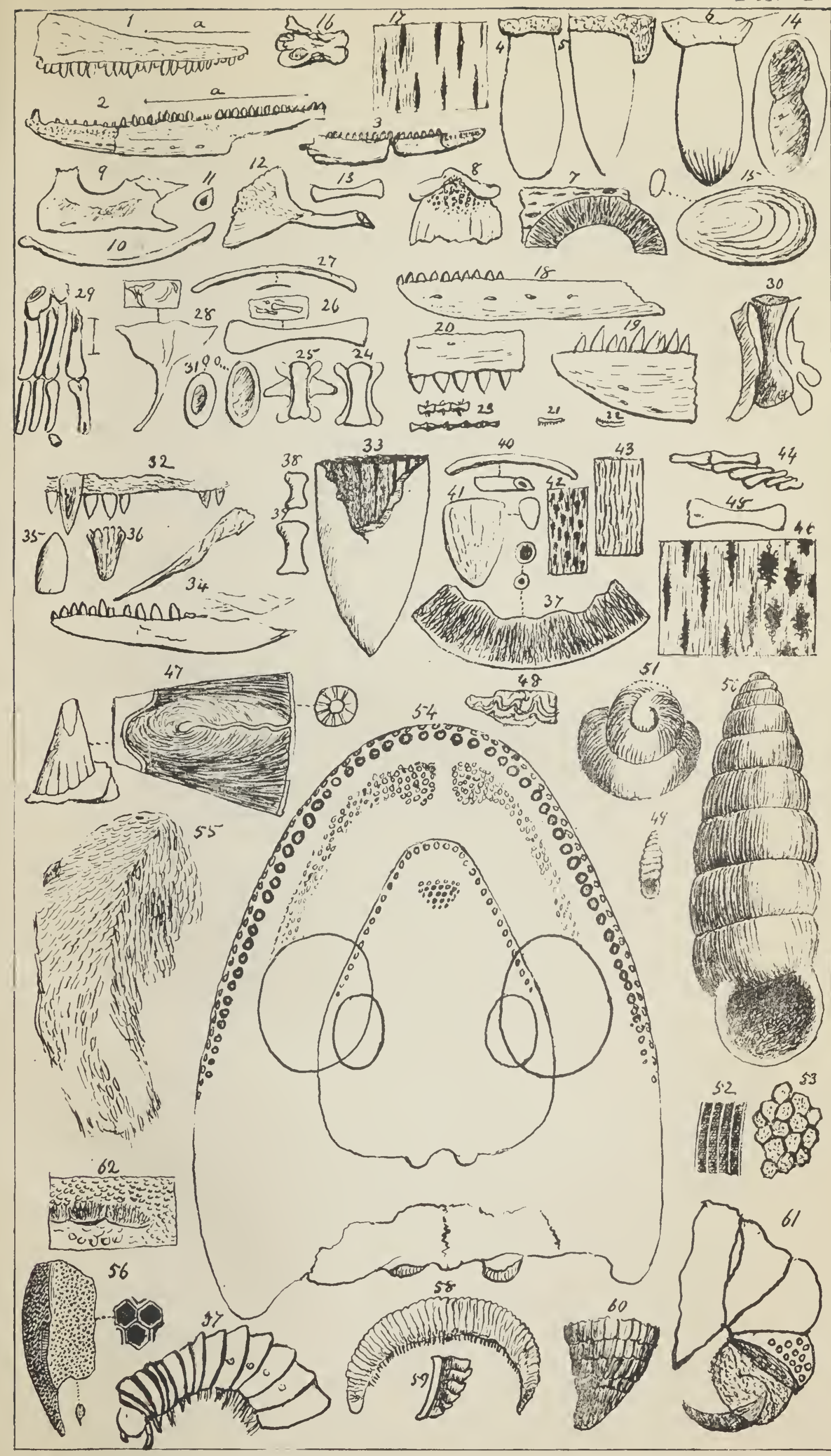

Sis.sedt 



\section{A I R-B REA THERS}

OF THF

\section{COAL PERIOD:}

A DESCRIPTIVE ACCOUNT OF THE REMAINS OF LANI ANIMALS, FOUND IN THE COAI, FORMATION

of

\section{NOV.I SOOTIA}

WITH REMARKS ON THEIR BEARING ON THEORIES OF THF FORMATION OF COAL AND OE THE ORIGIN OF SPECIER,

BY J. W. DAWSON, LL.D., F.R.S., F.G.S., ETC..

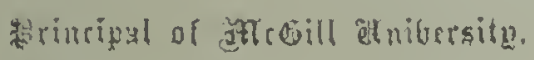

\section{WITH ILLUSTRATIONS}

\section{ittontreal:}

DAWSON, BROTHERS, GREAT ST. JAMES STREET, LONDON, B. BAILLIERE; XETY YORE, BAILLIERE, BROTHERS.

1863. 


6.

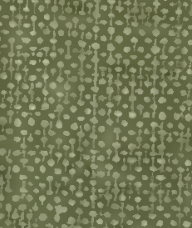

s.

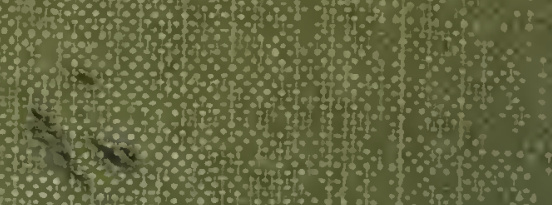

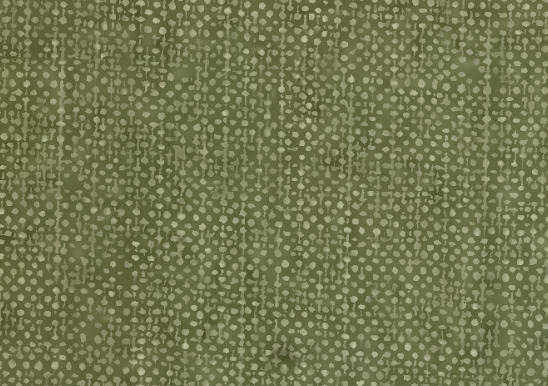

K. in $8 \%$

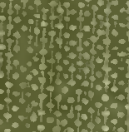

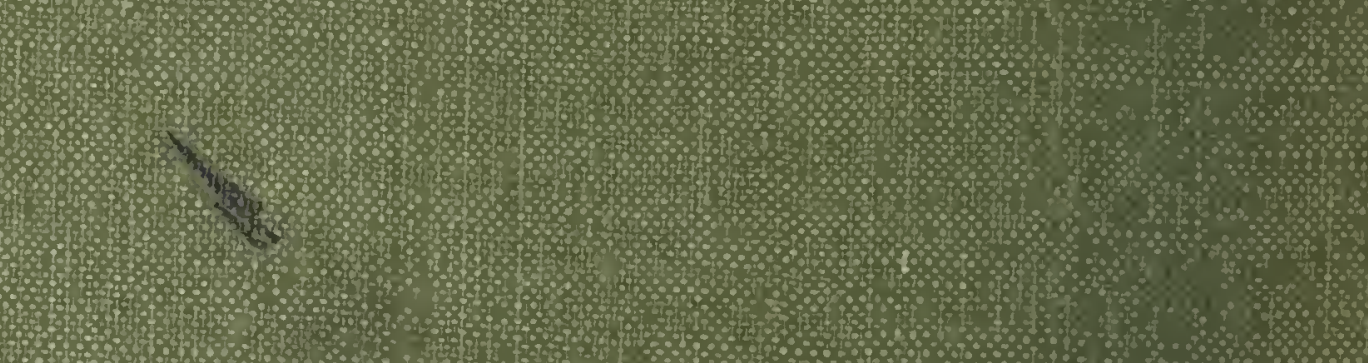

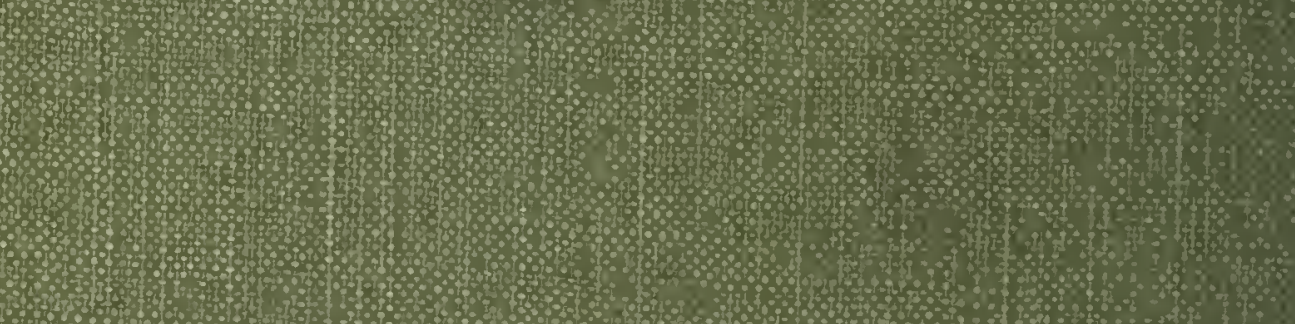

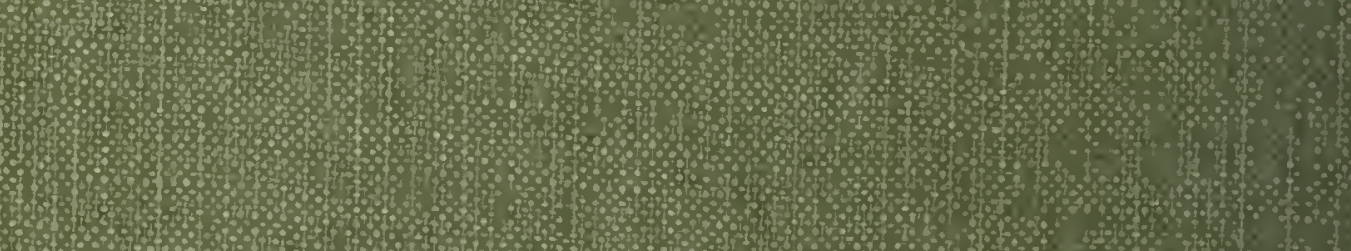
X.

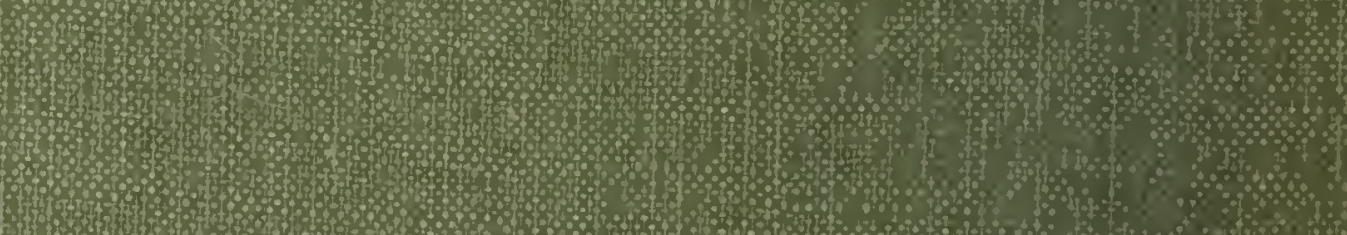

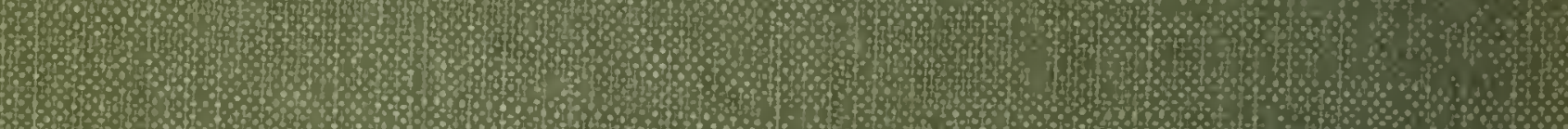

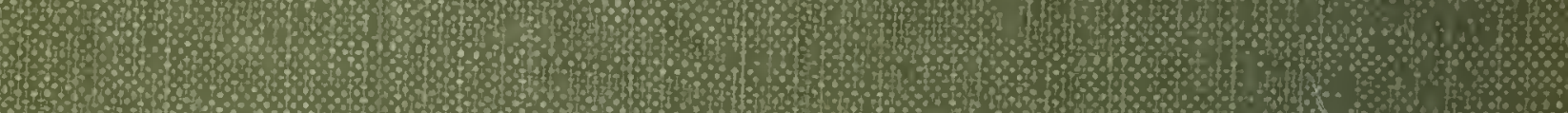

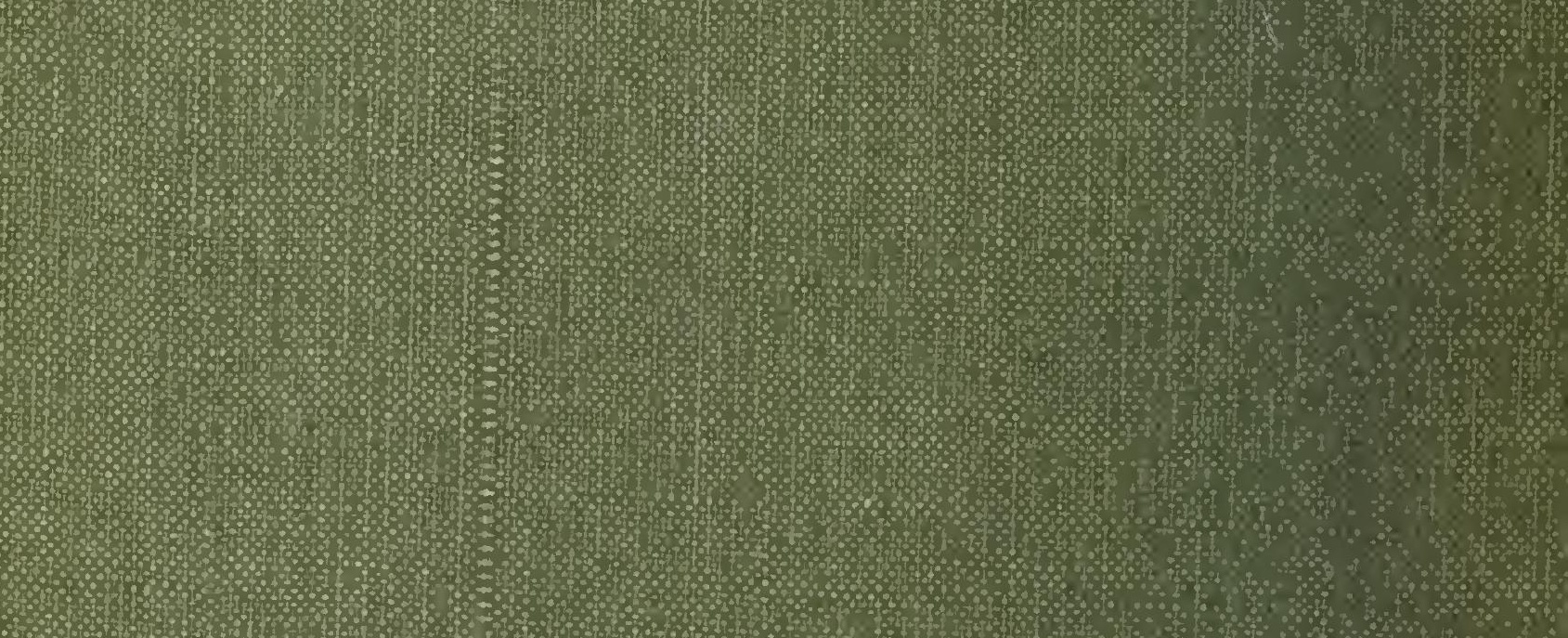

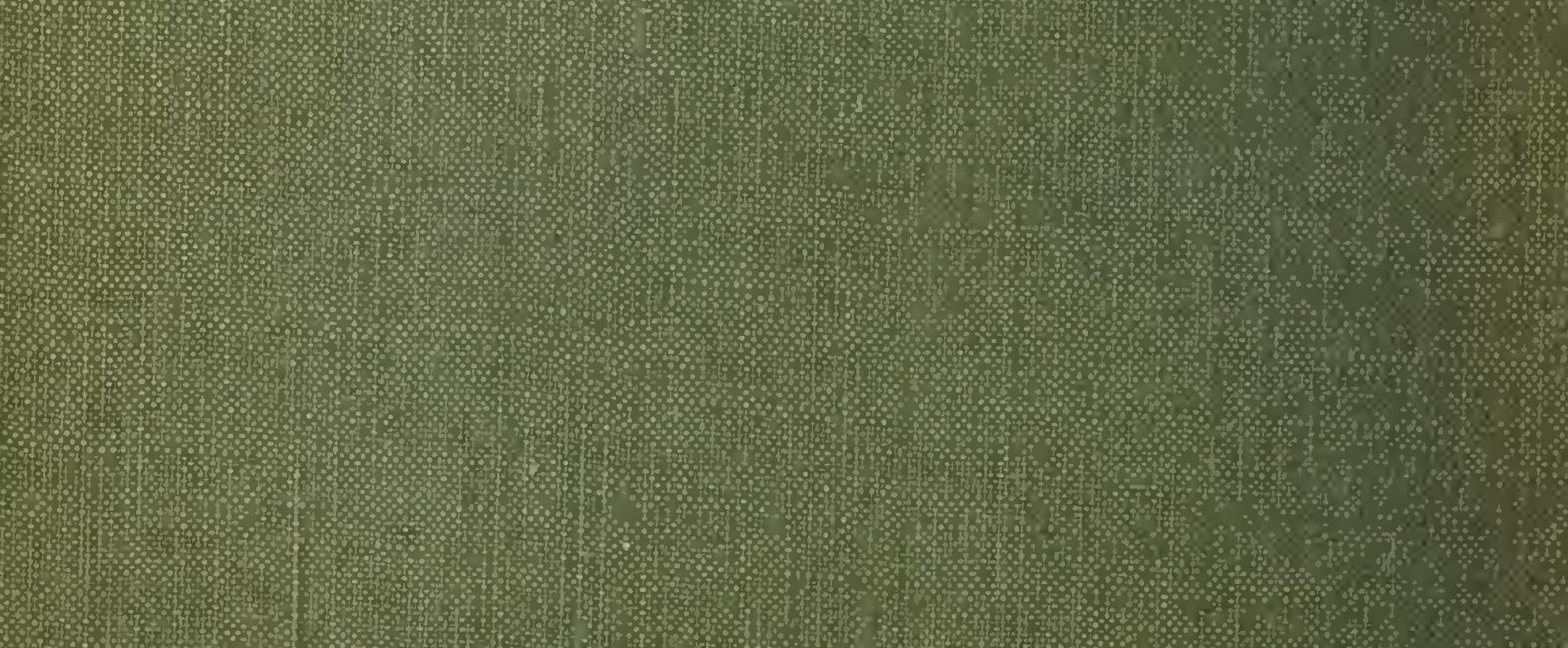

